\title{
Hydrothermal W-Mo mineralization of the Cheongyang mine, Republic of Korea : A fluid inclusion and stable isotope study
}

\author{
So Chil-Sup*, Yun Seong-Taek ${ }^{* *}$ and Lee Jae-Ho* \\ * Department of Geology, Korea University, Seoul 136-701, Korea \\ ** Department of Mineral and Energy Resources Engineering, \\ Semyung University, Jecheon 390-230, Korea
}

\begin{abstract}
The Cheongyang W-Mo mine, about $120 \mathrm{~km}$ south of Seoul, is composed of fissure-filling quartz veins within Cretaceous granite porphyry (70.5 $\pm 1.6 \mathrm{Ma})$ and Precambrian banded biotite gneiss. The spatial distribution of mineralized veins exclusively within or near the granite porphyry and related acidic dykes indicates that $\mathrm{W}$-Mo mineralization was associated with intrusion of the granite porphyry. The major ore minerals are wolframite, scheelite and molyb. denite. Ore mineralization can be divided into three distinct stages: greisen, vein (early $\mathrm{W}-\mathrm{Mo}$, and late base-metal sulfides), and vug (carbonates).

Fluid inclusion data indicate that the hydrothermal system at Cheongyang evolved from initial high temperatures (near $400^{\circ} \mathrm{C}$ ) to later lower temperatures (near $150^{\circ} \mathrm{C}$ ) from fluids with salinities between 0 and $6 \mathrm{wt}$ \% eq. $\mathrm{NaCl}$. Deposition of $\mathrm{W}$-Mo minerals occurred at temperatures between $300^{\circ}$ and $400^{\circ} \mathrm{C}$ mainly as a result of $\mathrm{pH}$ increase due to vapor loss by fluid boiling. Later deposition of base-metal sulfides and carbonates was the result of increasing influx of cooler meteoric waters. Fluid inclusion evidence of boiling during the early W-Mo mineralization indicates pressures 100 to 260 bars. Fluid inclusion data for the Cheongyang W-Mo deposits are similar with those of $\mathrm{W}$-Mo deposits in the Hwanggangri district, and are quite different with those of deposits in the Pusan-Yangsan district. This difference in temperature and compositions of hydrothermal fluids for Korean vein-type W-Mo deposits may reflect different pressure-depth conditions of W-Mo mineralization associated with late Cretaceous granitic activity in Korea.

Sulfur isotope compositions of sulfide minerals are consistent with an igneous source of sulfur with a $\delta^{34} \mathrm{~S}_{\delta s}$ value near 4 per mil. There is a systematic decrease in calculated $\delta^{18} \mathrm{O}_{\text {water }}$ values with increasing paragenetic time in the Cheongyang hydrothermal system, from values of $\approx 8$ per mil for greisen formation and $W$-Mo mineralization, to $\approx 3$ per mil for base-metal sulfide mineralization, to $\approx-2$ per mil for carbonate mineralization in vugs. There is a small increase in $\delta^{18} \mathrm{O}_{\text {water }}$ values from greisen formation $(6.3-6.8 \%$ o $)$ to $\mathrm{W}$-Mo mineralization $(7.0-7.8 \%$ ) , likely indicating boiling of ore fluids during $\mathrm{W}$-Mo mineralization. The trend of overall decrease in ${ }^{18} \mathrm{O}_{\text {water }}$ values with time is interpreted to indicate progressive meteoric water inundation of an early magmatic $\mathrm{W} \cdot$ Mo hydrothermal system.
\end{abstract}

Keywords: Cheongyang mine, Korea, Tungsten-molybdenum, Quartz veins, Mineralogy, Fluid inclusions, Stable isotopes.

\section{Introduction}

Vein-type W-Mo deposits in Korea are located in three major districts: Hwanggangri, Pusan-Yangsan, and Cheongyang. Previous studies have shown that vein-type $\mathrm{W}-\mathrm{Mo}$ deposits in Korea display similarities in temperatures of mineralization, ore fluid salinities, pressure depth conditions, mineralogy and paragenesis, and mineralization ages (Park and 


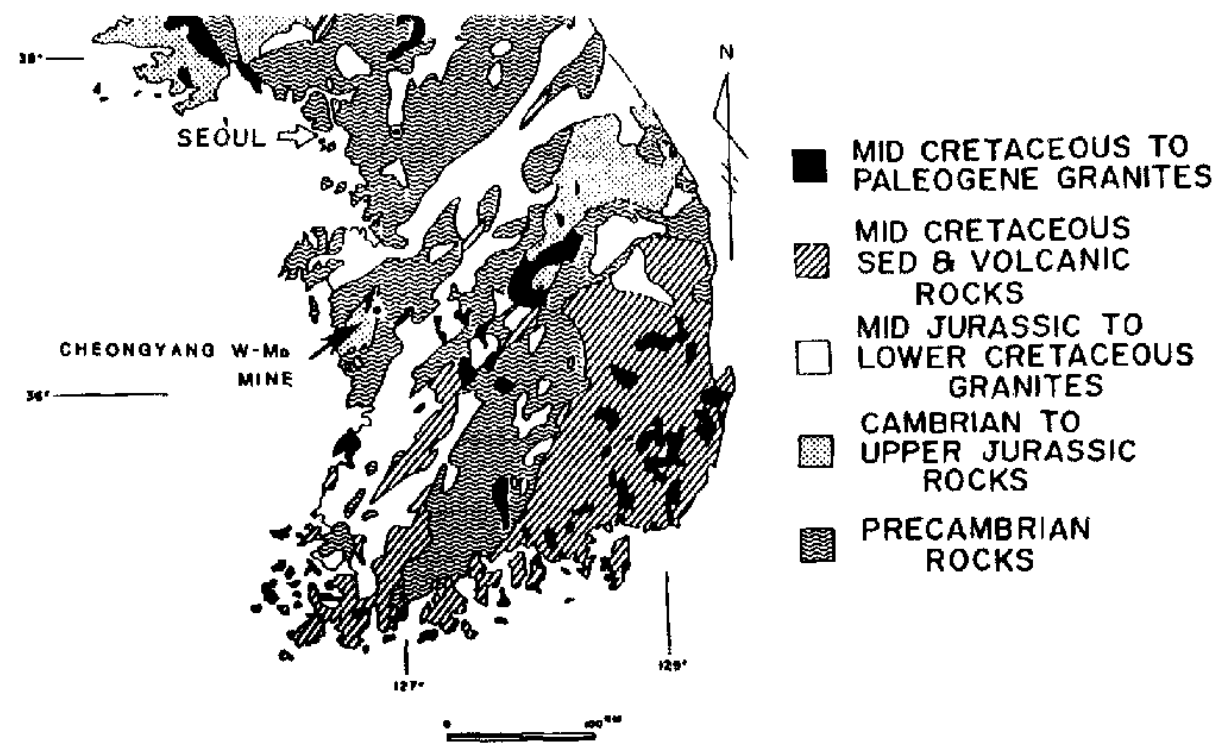

Fig. 1. Simplified geologic map of the Republic of Korea showing location of the Cheongyang W-Mo mine.

Choi, 1974 ; Park et al., 1981 ; So et al., 1983a, b, 1991 ; Kim, 1984 ; Kim, 1985 ; Shelton et al., 1986, 1987). Temperatures of tungsten deposition in most of these deposits range from $210^{\circ}$ to $380^{\circ} \mathrm{C}$, salinities vary from 2 to $14 \mathrm{wt} \%$ eq. $\mathrm{NaCl}$, depths of mineralization range from $<1.0$ to $2.5 \mathrm{~km}$, and ages of mineralization are all late Cretaceous. Stable isotope studies of these depositis indicate early magmatic hydrothermal fluids during W-Mo concentration and later involvement of meteoric waters (So et al., 1983a, 1991 ; Shelton et al., 1987).

The Cheongyang W-Mo mine is located approximately $120 \mathrm{~km}$ south of Seoul and lies in the Precambrian Gyeonggi metamorphic belt. The mine was one of the important W-Mo producers in Korea. Tungsten grades of the mine are 0.8 to $25 \mathrm{wt}$. \% $\mathrm{WO}_{3}$. Ore reserves are an estimated 113,000 tons of tungsten. During the mid-1940's, about 70 metric tons annually of beryl was also mined from ores containing about $3 \% \mathrm{BeO}$.

Previous studies have included the geology and fluid inclusions of the Cheongyang mine
(Kim, 1977; Park and Choi, 1981). However, little is known about the physicochemical conditions and evolution of ore deposition. The present study aims to document the age and nature of ore mineralization, to elucidate the origin and geochemical environments of oreforming fluids, and to compare the data with other vein-type W-Mo deposits in Korea.

\section{General geology}

The Cheongyang W-Mo mine lies within the southwestern region of the Gyeonggi metamorphic belt (Fig. 1). Geology of the mine area is simple, consisting largely of Precambrian gneisses which are intruded by Cretaceous granite porphyry and related dykes (Fig. 2). Geology of the mine area has been described in detail by Kim (1977).

Precambrian metamorphic rocks in the mine area consist largely of banded biotite gneiss with minor intercalations of amphibolite. Granitic gneiss and porphyroblastic gneiss occur locally with gradational contacts with banded biotite gneiss. These metamorphic 


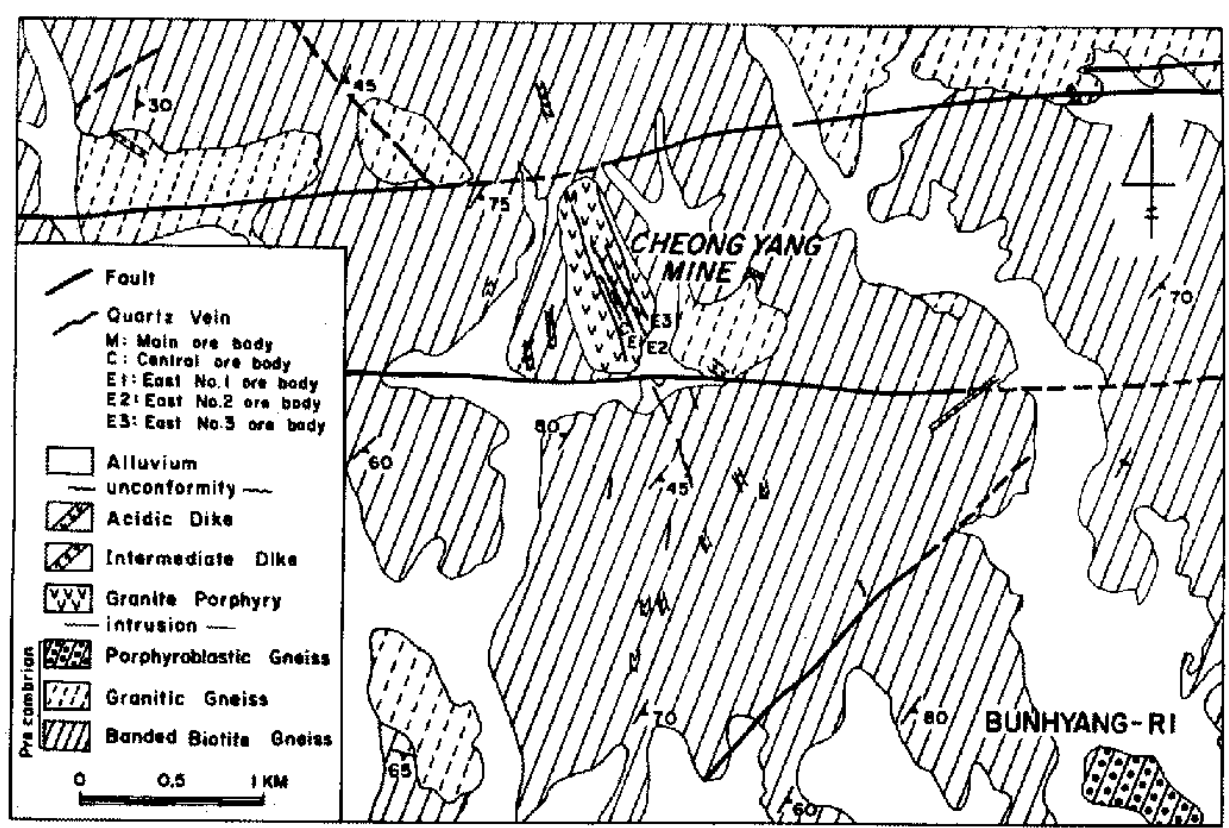

Fig. 2. Geologic map of the Cheongyang W-Mo mine area showing locations of major orebodies.

rocks have been folded into a northeastly-striking syncline and are broken by $\mathrm{E}-\mathrm{W}$-trending fractures.

A small body of granite porphyry intrudes the banded biotite gneiss. Phenocrysts of quartz and potassium feldspars are characteristic of the granite porphyry but gradually decrease in amounts at depth. Granite porphyry has been extensively greisenized by $\mathrm{W}$ Mo-bearing hydrothermal solutions. These greisenized rocks characteristically contain muscovite, beryl, wolframite and fluorite. A series of NW-trending, acidic to intermediate dykes (each $<1 \mathrm{~km}$ long and 5-50 $\mathrm{m}$ thick) are widespread, especially around the mine area, as fillings of tensional open spaces in Precambrian gneiss. Some fractures within these dykes are filled by $\mathrm{W}$-Mo-bearing quartz veins.

Whole-rock K-Ar dating of the granite porphyry indicates an age of $70.5 \pm 1.6 \mathrm{Ma}$ (Table 1). Spatial distribution of W-Mo quartz veins within or near the granite porphyry and the related dykes (Fig. 2) indi- cates that W-Mo mineralization of the Cheongyang mine was genetically associated with late Cretaceous granitic activity.

\section{Ore deposits}

Within the Cheongyang mine, more than 15 subparallel W-Mo-bearing hydrothermal quartz veins are developed along steeply dipping faults and related joints mainly in granite porphyry (Fig. 2). The veins can be traced along strike direction $\left(\mathrm{N} 15^{\circ}-30^{\circ} \mathrm{W}\right)$ up to $2 \mathrm{~km}$ and have variable thickness of 0.2 to $1.0 \mathrm{~m}$. The Cheongyang mine consists of five major orebodies (Fig. 2): Main, Central, East No.1, East No. 2, and East No. 3 orebodies.

The mineralogy of the veins consists main. ly of quartz, muscovite, fluorite and calcite with W-Mo minerals and base-metal sulfides. The principal gangue mineral is coarse crystalline white quartz, comprising up to $85-90$ volume $\%$ of the veins. The principal ore mineral is wolframite.

Based on crude mineralogical bands and 
Table 1. K-Ar data of granite porplyry from the Cheongyang $\mathrm{W}-\mathrm{Mo}$ mine area

\begin{tabular}{|c|c|c|c|c|}
\hline Sample no. & $X(w t, x)$ & $\begin{array}{c}\text { Rediogenis }{ }^{40} \mathrm{Ar} \\
\left(10^{-} \mathrm{b}_{\mathrm{CC}} \mathrm{STP} / \mathrm{g}\right)\end{array}$ & $\begin{array}{l}\text { Non Red. } \\
\text { Ar (x) }\end{array}$ & $\begin{array}{c}\text { Date } \\
\left\{M_{0} \pm 1 \mathfrak{d}\right\}\end{array}$ \\
\hline $\mathrm{CY}-2$ & 3.64 & 1014 & 11.2 & $70.5 \neq 1.6$ \\
\hline
\end{tabular}

occurrences of vein minerals, the following sequence of mineral precipitation is recog. nized: wolframite +molybdenite \pm scheelite with quartz, muscovite and beryl $\rightarrow$ base-metal sulfides with quart $\rightarrow \rightarrow$ fluorite + carbonates in vugs. Mineralized veins of the Cheongyang mine also show a vertical compositional zoning with depth. Wolframite and base-metal sulfides are more concentrated in upper por. tions of the veins, whereas molybdenite tends to be more enriched in lower vein portions. According to assay results of ores, subeconomic grades of gold and silver are often associated with base-metal-rich ores from upper vein portions.

\section{Mineralogy and paragenesis}

Hydrothermal activity of the Cheongyang mine can be divided into three stages, as shown in Fig. 3 , i.e., greisen, vein, and vug stages. The first stage was early quart $z+$ muscovite greisen formation, Quartz veins with $\mathrm{W}-\mathrm{Mo}$ minerals and base-metal sulfides formed in the second stage. The last stage is represented by the carbonates + fluorite deposition in vugs.

\section{Greisen Stage}

Intense greisenization of wall rocks is recognized in the mine area. Practically all of the orebodies are hosted and surrounded by quart $z+$ muscovite \pm beryl greisens. These greisen zones have variable thickness from 0.1 to $0.6 \mathrm{~m}$, and are variable in composition according to the nature of wall-rocks.

Granite porphyry adjacent to W-Mo veins was most strongly altered to quartz +muscovite + beryl greisen in which quartz $(<87 \mathrm{vol}$.
$\%$; determined by point counting), beryl $(<58$ vol. \%), muscovite ( $<26$ vol. \%), and minor amounts of rutile and fluorite $(<1$ vol. \%) are typically present, mainly as fine disseminations. Wolframite, molybdenite and pyrite are also disseminated in this inner greisen zone. The amounts of muscovite and beryl decrease from inner to outer zone in the greisen. In the contacts between $\mathrm{W}-\mathrm{Mo}$ veins and banded biotite gneiss, only quart $z+$ muscovite greisen is observed. Quartz+muscovite greisen developed in gneiss is characterized by abundant fuorite (up to $3 \mathrm{vol} . \%$ ) and rare beryl compared with quart $z+$ muscovite \pm beryl greisen in granite porphyry.

\section{Vein Stage}

Vein stage is characterized by the earlier W-Mo ores +quartz mineralization and the later base-metal sulfides+quartz mineralization (Fig. 3).

Earlier W-Mo mineralization is character. ized by the precipitation of molybdenite, wolframite, and scheelite accompanying quartz, muscovite, and beryl. Muscovite occurs as fine disseminations within coarse crystalline white quartz and as well-defined mineralic bands along the vein contacts with wall rocks. Beryl occurs as white to light green aggregates of hexagonal crystals $(0.1$ to $5.0 \mathrm{~cm}$ in length) which are intergrown with quartz and muscovite. Molybdenite occurs as fine dissemina. tions and/or massive aggregates in quartz veins. Rare, prismatic or bladed bismuthinite is intergrown with or overgrows molybdenite. Wolframite, the main ore constituent, is distributed unevenly in the veins as columnar or platy crystals of $0.1-4.0 \mathrm{~cm}$ long and sometimes in central vein portions as segregations of large grains, often forming nests. According to Kim (1977), wolframite from the Cheongyang mine has $\mathrm{MnO} / \mathrm{FeO}$ ratios ranging from about 0.80 to 0.95. Scheelite is present in the form of fine anhedral grains within quartz matrix and is 


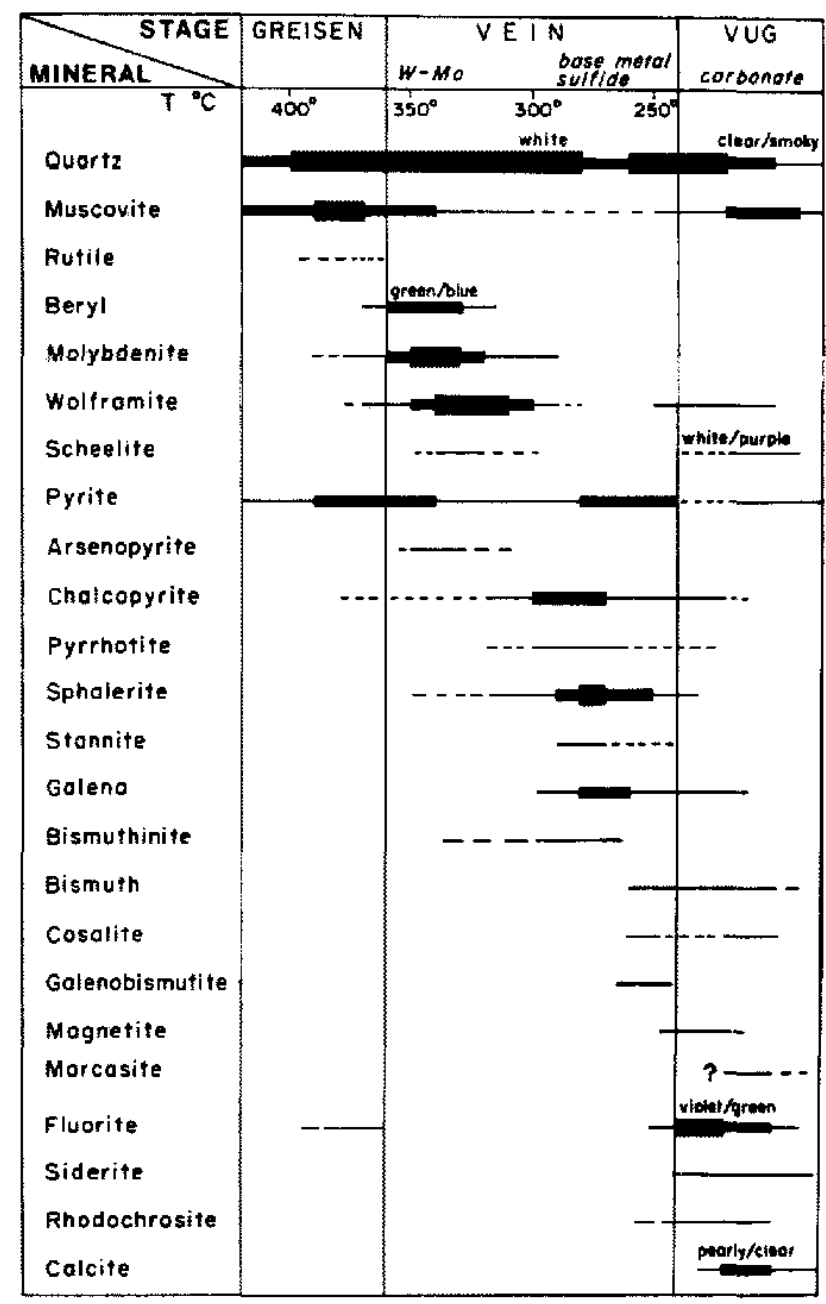

Fig. 3. Mineral paragenesis of the Cheongyang W-Mo mine. Width of lines corresponds to relative abundance. The temperature scale is based on analysis of fiuid inclusion data and temperature estimation using mineral assemblages.

often associated with wolframite. Some scheelites occur along margins and fractures of quartz grains. Scheelite shows white to yellow fluorescence color under UV light, indicating the presence of minor powellite component. Pyrite and chalcopyrite are present rarely in wolframite as fine euhedral to subhedral inclusions. Pyrrhotite occurs in irregular fractures of wolframite. Pyrite usually forms aggregates intergrown with wolframite, molybdenite and sphalerite (15.3-19.2 mole \% FeS; Table 2, Fig. 4). Fine arsenopyrites (29.7-31.0 atom. \%
As) are often intergrown with pyrite.

Later base-metal mineralization is characterized by deposition of abundant base-metal sulfides. Sphalerite occurs mainly as polycrystalline aggregates in central vein portions and is often intergrown with chalcopyrite and pyrite. It commonly contains small blebs of pyrite, chalcopyrite and pyrrhotite. Sphalerite from the base-metal stage displays wide compositional variations from 12.6 to 17.8 mole $\%$ FeS (Table 2, Fig. 4). Stannite occurs locally as massive aggregates closely inter- 
Table 2. Partial analyses of sphalerite from the Cheongyang $\mathrm{W}-\mathrm{Mo}$ mine

\begin{tabular}{|c|c|c|c|c|}
\hline \multirow{2}{*}{$\begin{array}{c}\text { Sample } \\
\text { no. }\end{array}$} & \multirow[b]{2}{*}{ stage } & \multicolumn{3}{|c|}{ mole percent } \\
\hline & & Fes & $\mathrm{M} n S$ & $\operatorname{cas}$ \\
\hline \multirow[t]{6}{*}{$C \gamma-22$} & vein & 19.2 & 0.3 & 1.6 \\
\hline & $\left(W-M_{0}\right)$ & 17.5 & 0.3 & 1.2 \\
\hline & & 15.7 & 0.3 & 0.2 \\
\hline & & 16.0 & 0.4 & 0.1 \\
\hline & & 18.2 & 0.3 & 1.0 \\
\hline & & 15.5 & 0.4 & 0.3 \\
\hline \multirow[t]{6}{*}{$\mathrm{CY}-23$} & vein & 17.7 & 0.4 & 1.0 \\
\hline & $\left(W-M_{0}\right)$ & 15.7 & 0.4 & 0.3 \\
\hline & & 15.3 & 0.3 & 0.3 \\
\hline & & 15.7 & 0.4 & 0.2 \\
\hline & & 16.2 & 0.4 & 0.2 \\
\hline & & 16.4 & 0.3 & 0.4 \\
\hline \multirow[t]{8}{*}{$C Y-33$} & veìn & 17.8 & 0.0 & 0.0 \\
\hline & (hase-wetal & 13.1 & 0.0 & 0.0 \\
\hline & sulfide) & 16.4 & 0.0 & 0.0 \\
\hline & & 14.4 & D. 0 & 0.0 \\
\hline & & 14.5 & 0.0 & 0.0 \\
\hline & & 16.5 & 0.0 & 0.0 \\
\hline & & 16.7 & 0.0 & 0.0 \\
\hline & & 17,6 & 0.0 & 0.0 \\
\hline \multirow[t]{3}{*}{$C Y-41$} & vein & 13.6 & 0.0 & 0.0 \\
\hline & (base-metal & 16.3 & 0.0 & 0.0 \\
\hline & gulfide) & 12.6 & 0.0 & 0.0 \\
\hline \multirow[t]{2}{*}{$C Y-35$} & vug & 19.3 & 0.0 & 1.6 \\
\hline & (carbonate) & 18.3 & 0.0 & 1.9 \\
\hline \multirow[t]{7}{*}{$C X-36$} & vug & 20.8 & 0.0 & 2.5 \\
\hline & (carbonate) & 22.0 & 0.0 & 3.1 \\
\hline & & 21.3 & 0.0 & 2.9 \\
\hline & & 19.0 & 0.0 & 2,9 \\
\hline & & 21.6 & 0.0 & 3,4 \\
\hline & & 22.7 & 0.0 & 5.2 \\
\hline & & 23.3 & 0.0 & 5.1 \\
\hline \multirow[t]{2}{*}{$c y-40$} & vug & 23.4 & 0.0 & 2.6 \\
\hline & (carbonate) & 23.3 & 0.0 & 2.2 \\
\hline \multirow[t]{3}{*}{$C Y-51$} & vus & 22.1 & 0.4 & 1,3 \\
\hline & (carbonete) & 21.4 & 0.4 & 1,4 \\
\hline & & 19.7 & 0.3 & 1.6 \\
\hline
\end{tabular}

grown with sphalerite, and often contains pyrite inclusions. Galena penetrates and replaces nearly all of the early-deposited sulfides and is intimately associated with $\mathrm{Pb}-\mathrm{Bi}$ sulfosalts (cosalite and galenobismutite) and native bismuth.

\section{Vug Stage}

Quartz, muscovite, fluorite, carbonates and minor amounts of ore minerals were deposited in vugs. Euhedral quartz $(<10 \mathrm{~cm}$ long) is clear to smoky in color. Carbonate minerals, mainly calcite with minor siderite and rhodochrosite, occur as rhombs overgrowing prismatic quartz. Purple and pale green fluorite are commonly associated with carbonates in vugs. Muscovite occurs mainly at the base of vugs as coarse plates and often fills microfractures of vein quartz near vugs. Wolframite in vugs overgrows quartz as small euhedral crystals. White to purple euhedral scheelites $(<3 \mathrm{~cm}$ long) are often observed in vugs. Rare amounts of sulfides such as pyrite, chalcopyrite, pyrrhotite, sphalerite (18.3-23.4 mole \% FeS; Table 2, Fig. 4) and galena, and native bismuth occur as aggregates of euhedral to subhedral crystals in vugs, which are associated with muscovite and rhodochrosite and often overgrow scheelite. Magnetite occurs as microscopic-sized inclusions within pyrite and sphalerite in vugs.

\section{Comparison of Mineral Paragenesis to Other Tungsten Deposits}

The overall vein mineralogy of the Cheongyang W-Mo mine changed with increasing paragenetic time from $\mathrm{W}-\mathrm{Mo}$ minerals through base-metal sulfides to carbonates. Other Kor. ean W-Mo vein deposits (e.g., Daehwa, Weolag, Sannae, Gyeongchang) commonly show similar complex sequences of $\mathrm{W}-\mathrm{Mo}, \mathrm{Pb}-\mathrm{Zn}$, and carbonates mineralization rather than simple quartz-wolframite-molybdenite veins (Shelton et al., 1986; So et al., 1983a, b, 1991). Many famous worldwide $W$-bearing vein deposits $(e$. g., Pasto Bueno, Peru; Panasqueira, Portugal; San Cristobal, Peru) have similar complex mineralization sequences (Landis and Rye, 1974 ; Kelly and Rye, 1979 ; Campbell, 1983). This complex mineralization sequences in $\mathrm{W}$ bearing hydrothermal systems have been interpreted to be the results of later introduction of progressively larger volumes of cooler meteoric waters into early $\mathrm{W}-\mathrm{Mo}$-depositing magmatic hydrothermal systems (Shelton, 1984 ; So et al., 1991).

\section{Fluid inclusion studies}

Fluid inclusion studies (heating and freezing experiments) were performed on 32 thin $(<$ 
$1 \mathrm{~mm}$ ), doubly polished plates of quartz, beryl, rhodochrosite, fluorite and calcite, in order to document the ranges of fluid compositions and temperatures during the hydrothermal mineralization at Cheongyang. Microthermometric data were obtained using a Fluid Inc. gas-flowtype heating-freezing stage at Korea University. Salinity data are based on freezing-point depression in the system $\mathrm{H}_{2} \mathrm{O}-\mathrm{NaCl}$ for $\mathrm{H}_{2} \mathrm{O}$ rich inclusions (Potter et al., 1978) and on clathrate melting temperatures for $\mathrm{CO}_{2}$-bearing inclusions (Bozzo et al., 1975; Collins, 1979).

Minerals examined contain numerous primary and secondary inclusions. Three types of inclusions are recognized based on their phase relations at room temperature, as follows.

Type I (liquid-rich): This type of fluid inclusions contains liquid and a water-rich vapor phase, and homogenizes to the liquid phase. The vapor bubble usually makes up 20 to 50 percent of the total inclusion volume. Type I inclusions are predominant in all minerals examined. Some type I inclusions formed traces of gas hydrates during freezing runs, indicating that minor amounts of $\mathrm{CO}_{2}(\approx$ 0.85 molal, the level required for $\mathrm{CO}_{2}$ clathrate formation; Hedenquist and Henley, 1985) are contained in these inclusions.

Type II (gas-rich): This type of inclusion also contains a liquid and a water-rich vapor phase whose volume $(70-90$ volume $\%$ of the total inclusion volume) exceeds that of the liquid phase. Type II inclusions are observed only as primary inclusions in white quartz and beryl of the vein stage and homogenize to the vapor phase upon heating.

Type III $\left(\mathrm{CO}_{2}\right.$-bearing): This type of inclusion contains liquid $\mathrm{CO}_{2}, \mathrm{CO}_{2}$ vapor, and an agueous liquid at room temperature. The volumetric ratio of $\mathrm{CO}_{2}$ (liquid+vapor)/aqueous liquid at $25^{\circ} \mathrm{C}$ is about $1: 1$. Type III inclusions occur rarely in white quartz of vein stage
[W] W-Mo phase (Early)

B Base-melal sulfides phase (Late) VEIN STAGE

C] Carbonate phase (Vuc STAGE)

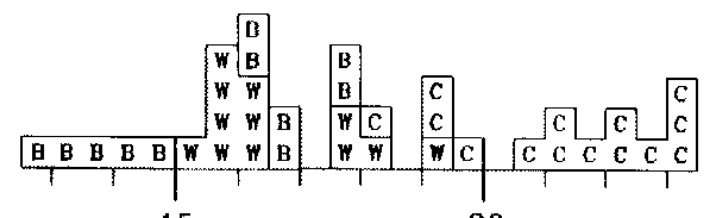

15

20

FeS mole \% in sphalerite

Fig. 4. Variation of FeS content of sphalerite from the Cheongyang $\mathrm{W}-\mathrm{Mo}$ mine.

as primary inclusions (we observed only five type III inclusions in all of the samples examined, but two homogenization temperature data were obtained due to thermal decrepitation during heating experiments). They homogenize totally to the $\mathrm{H}_{2} \mathrm{O}$-rich phase. Phase transition from solid $\mathrm{CO}_{2}$ to liquid $\mathrm{CO}_{2}$ during freezing experiments occurred at temperatures of $>-57^{\circ} \mathrm{C}$, indicating a relatively pure $\mathrm{CO}_{2}$-rich phase in type III inclusions ( $\mathrm{Hol}$ lister and Burruss, 1976).

\section{Fluid Inclusions from Vein Stage}

White quartz and beryl from the vein stage contain numerous fluid inclusions ranging from 5 to $100 \mu$ in size (typically $10-20 \mu \mathrm{m}$ ) which occur as both primary and secondary inclusions.

Homogenization temperatures of primary fluid inclusions in white quart $z$ from vein stage range from $180^{\circ}$ to $398^{\circ} \mathrm{C}$ (type I inclusions, $180^{\circ}$ $398^{\circ} \mathrm{C}$; type II inclusions, $313^{\circ}-390^{\circ} \mathrm{C}$; type III inclusions, $324^{\circ}-332^{\circ} \mathrm{C}$ ) (Fig. 5). Primary fluid inclusions in beryl homogenize at temperatures between $284^{\circ}$ and $359^{\circ} \mathrm{C}$ (type II inclusions, $350^{\circ}$ $359^{\circ} \mathrm{C}$ ) (Fig. 5).

Salinities of primary inclusions in white quartz from vein stage range from 0.7 to $6.1 \mathrm{wt}$. $\%$ eq. $\mathrm{NaCl}$ (type I, 0.7-6.1 wt. \%; type II, 1.8 2.4 wt. \%; type III, 3.8-4.3wt. \%) (Fig.6). Primary fluid inclusions in beryl have salinities 


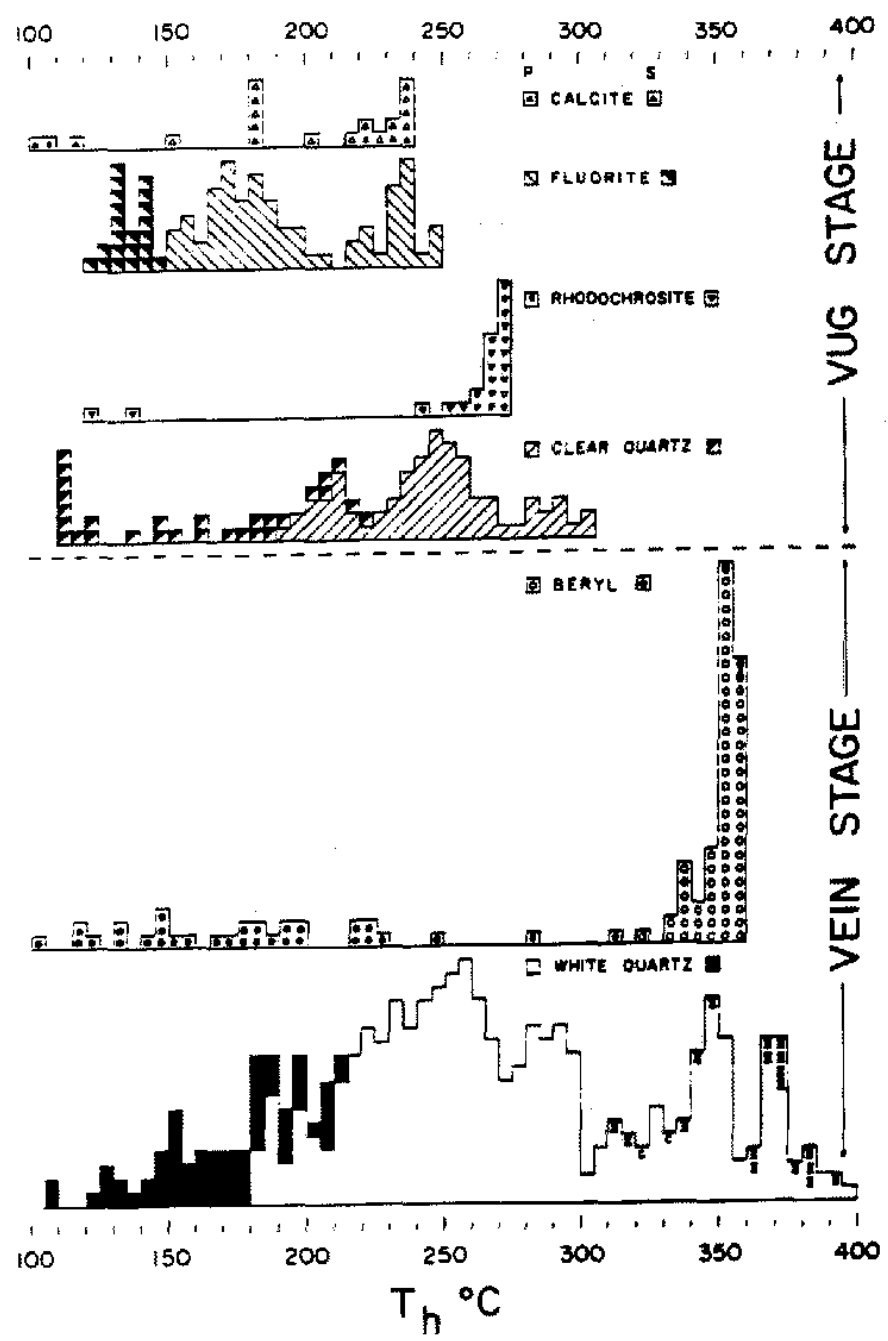

Fig. 5. Histograms of homogenization temperatures of fluid inclusions in minerals of the Cheongyang W-Mo mine.

Abbreviations: II, vapor-rich inclusions; $\mathrm{C}$, liquid $\mathrm{CO}_{2}$-bearing inclusions; $\mathrm{P}$, primary ; $\mathrm{S}$, secondary.

ranging from 3.1 to $4.6 \mathrm{wt}$ \% eq. $\mathrm{NaCl}$ (Fig. 6).

\section{Fluid Inclusions from Vug Stage}

Minerals examined from the vug stage are clear vug quartz, rhodochrosite, fluorite and calcite and they contain only type I inclusions. Homogenization temperature and salinity data for vug stage are shown in Figs. 5 and 6.

Homogenization temperatures of primary fluid inclusions in all examined minerals from the vug stage range from $150^{\circ}$ to $304^{\circ} \mathrm{C}$ (clear vug quartz, $194^{\circ}-304^{\circ} \mathrm{C}$; rhodochrosite, $240^{\circ}$ - $272^{\circ} \mathrm{C}$; fluorite, $152^{\circ}-248^{\circ} \mathrm{C}$; calcite, $150^{\circ}-237^{\circ} \mathrm{C}$ ) (Fig. 5). There is a general decrease of homogenization temperature from clear vug quartz (up to $\approx 305^{\circ} \mathrm{C}$ ) to calcite (down to $150^{\circ} \mathrm{C}$ ) (Fig. 5).

Salinities of primary inclusions in minerals from the vug stage range from 0.2 to $4.7 \mathrm{wt}$. \% eq. $\mathrm{NaCl}$ (clear vug quartz, $0.4-4.7 \mathrm{wt} \% \mathrm{NaCl}$; rhodochrosite, 1.8-3.1 wt. \%; fluorite, 1.6-3.2 wt. \% ; calcite, 0.2-2.4 wt. \%) (Fig. 6). 


\section{Variations in Temperature and Composi- tion of Hydrothermal Fluids}

Variations in temperature and composition of hydrothermal fluids throughout the hydrothermal activity are recognized by fluid inclusion studies. Fluid inclusion homogenization temperature data indicate that hydrothermal fluids at Cheongyang evolved from initial high temperatures $\left(\approx 400^{\circ} \mathrm{C}\right)$ to later lower temperatures $\left(\approx 150^{\circ} \mathrm{C}\right)$.

Homogenization temperatures of primary inclusions in white quartz from the vein stage range from $180^{\circ}$ to $400^{\circ} \mathrm{C}$. Within this wide range of temperatures, analysis of peaks and clusters of data within a frequency diagram (Fig. 5) has allowed us to decipher individual events which are likely related to specific mineral assemblages (Shelton, 1983).

Homogenization temperatures of primary inclusions in white vein quartz form two main clusters (Fig. 5): a high-temperature cluster, from $300^{\circ}$ to $400^{\circ} \mathrm{C}$, possibly corresponding to early quart $2+\mathrm{W}-$ Mo mineralization; and a lower temperature cluster, from $300^{\circ}$ to $180^{\circ} \mathrm{C}$, corresponding to late quart $z+$ base-metal sulfide mineralization.

The relationship between homogenization temperature and salinity for vein stage indicates a history of fluid boiling during $\mathrm{W}$-Mo mineralization (Fig. 7). Prolonged and extensive boiling of vein-stage ore fluids resulted in a progressive increase in salinity from $\approx 1 \mathrm{wt}$. $\%$ eq. $\mathrm{NaCl}$ to $\approx 5$ wt. $\%$ eq. $\mathrm{NaCl}$, as vapor loss during boiling resulted in concentration of salts in residual fluids. $\mathrm{CO}_{2}$-bearing type $\mathrm{III}$ inclusions in white vein quartz may represent the trapping of an immiscible $\mathrm{CO}_{2}$-rich vapor formed by boiling of parent $\mathrm{H}_{2} \mathrm{O}-\mathrm{CO}_{2}$ fluids.

Salinities of low-temperature $\left(<250^{\circ} \mathrm{C}\right)$, secondary inclusions in white quart $z$ and beryl from the vein stage are about 2.5 to $5 \mathrm{wt}$. \% eq. $\mathrm{NaCl}$, which are comparable to those of primary inclusions (Fig. 6). Fracturing was pres-

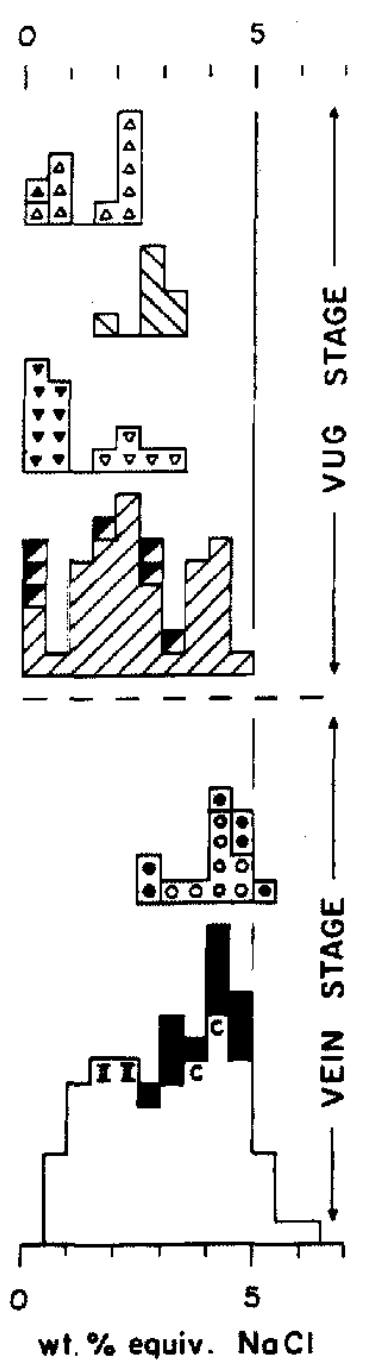

Fig. 6. Histograms of salinities of fluid inclusions in minerals of the Cheongy ang $\mathrm{W}$-Mo mine. Symbols are the same as in Fig. 5.

ent throughout all of the episodes of mineraliza. tion at Cheongyang. It is therefore likely that high-salinity fluids generated by extensive fluid boiling were trapped continuously as secondary inclusions in earlier-deposited, white quartz and beryl.

Fluid inclusion data from the vug stage mineralization reflect much cooler $\left(300^{\circ}-150^{\circ} \mathrm{C}\right)$, 


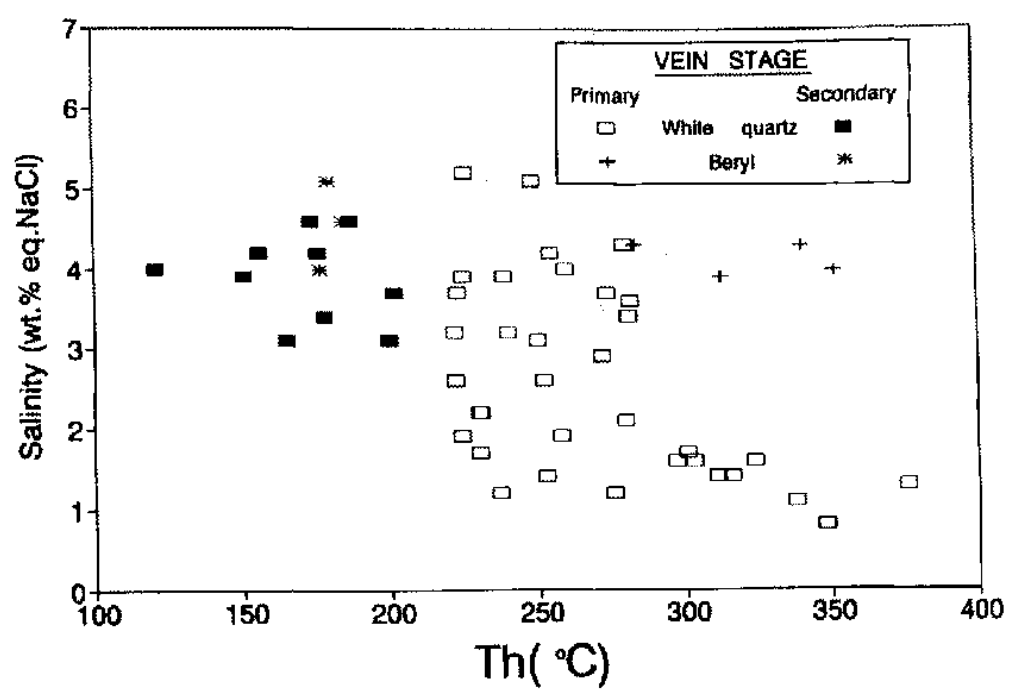

Fig. 7. Homogenization temperature versus salinity diagram for fluid inclusions in minerals of vein stage of the Cheongyang W-Mo mine.

progressively more dilute (down to $\approx 0$ wt. $\%$ eq. $\mathrm{NaCl}$ ) hydrothermal fluids as a result of increasing influx of cooler, dilute meteoric waters (Figs. 5 and 6, see also "Stable Isotope Studies").

\section{Pressure-Depth Consideration and Significance of Fluid Boiling}

Liquid-rich (type I) and vapor-rich (type II) fluid inclusions are intimately associated in samples of white quartz and beryl from the vein stage and homogenize at similar temperatures $\left(310^{\circ}\right.$ to $\left.390^{\circ} \mathrm{C}\right)$. This indicates that hydrothermal fluids during the early W-Mo mineralization boiled extensively. No pressure corrections are therefore necessary for these hightemperature fluid inclusions because they were trapped along a liquid-vapor curve in the system $\mathrm{H}_{2} \mathrm{O}-\mathrm{NaCl}$.

The data of Sourirajan and Kennedy (1962) and $\mathrm{Haas}$ (1971) for the system $\mathrm{H}_{2} \mathrm{O}-\mathrm{NaCl}(1-6$ wt. \%) indicate a range of pressures from $\approx 100$ to 260 bars at the time of fluid entrapment. This range of pressures corresponds to mineralization depths near $1 \mathrm{~km}$ if pressure conditions changed from lithostatic toward hydrostatic regimes. The wide temperature range of vapor-rich type II inclusions $\left(310^{\circ}-390^{\circ} \mathrm{C}\right)$ and the progressive increase of fluid salinity with decreasing temperature (Fig. 7) likely indicate that W-Mo-depositing hydrothermal fluids at Cheongyang evolved continuously near boiling conditions.

Progressive vapor loss from hydrothermal fluids due to boiling can result in chemical changes (e.g., $\mathrm{pH}, \mathrm{fo}_{2}, \Sigma \mathrm{H}_{2} \mathrm{O}, \Sigma \mathrm{CO}_{2}$ etc.) in the liquid phase (Drummond and Ohmoto, 1985). Wolframite deposition is favored by increase in $\mathrm{pH}$ of ore fluids by the following reaction (Polya, 1987): $\mathrm{FeCl}^{+}+\mathrm{HWO}_{4}{ }^{-} \rightarrow \mathrm{FeWO}_{4}+\mathrm{H}^{+}+$ $\mathrm{Cl}^{-}$. Tungsten deposition in the Cheongyang hydrothermal systems was probably a result of $\mathrm{pH}$ increase due to vapor loss accompanied by cooling during fluid boiling.

\section{Comparison of Fluid Inclusion Data with Other Korean W-Mo Vein Deposits}

Several Korean hydrothermal vein-type tungsten-molybdenum deposits (e.g., Daehwa, Weolag, Sannae, Gyeongchang, Susan etc.) have been the subjects of detailed fluid inclusion studies (Park and Choi, 1974; Park et al., 1981; Kim, 1985; Shelton et al., 1986, 1987; So et al., 1983a, b, 1991). Vein-type W-Mo deposits in 
Table 3. Comparison of selected features of Korean hydrothermal vein-type W-Mo deposits

\begin{tabular}{|c|c|c|c|c|c|c|}
\hline $\begin{array}{l}\text { Vine } \\
\text { district }\end{array}$ & Mine & Geolosy & Ore occurrence ${ }^{1)}$ & Alteration & $\begin{array}{l}\text { Mineralization } \\
\text { age (Ma) }\end{array}$ & $\begin{array}{l}\infty_{2} \text {-bearing } \\
\text { inclusions }\end{array}$ \\
\hline Cheongyang & Cheongyang & $\begin{array}{l}\text { Granite porphyry } \\
(70.5 \mathrm{Ma}) \text { in gneiss }\end{array}$ & $\begin{array}{l}\text { Quarty veins with } \\
\text { wf +motschiabun- } \\
\text { dant eulfides, } \\
\text { Pb-Bi sulfosalts }\end{array}$ & $\begin{array}{l}\text { Greisen, } \\
\text { chloritic }\end{array}$ & $70.5 \pm 1.6$ & rare \\
\hline \multirow[t]{3}{*}{ thranggangri } & Daehwa & $\begin{array}{l}\text { Granite }(87.6 \mathrm{Ma} \text { ) } \\
\text { in gneiss }\end{array}$ & $\begin{array}{l}\text { Quartz veing with } \\
\text { wf+motschiminor } \\
\text { sulfides }\end{array}$ & $\begin{array}{l}\text { Greisen, } \\
\text { chloritic }\end{array}$ & $87.6 \pm 1.6(?)$ & $\begin{array}{l}\text { minor } \\
(<10 \text { mole } \\
\left.\times \mathrm{CO}_{2}\right)\end{array}$ \\
\hline & Weolag & $\begin{array}{l}\text { Granite }(87-90 \mathrm{Mb}) \\
\text { in linestones }\end{array}$ & $\begin{array}{l}\text { Ouartz veins with } \\
\text { wf +sch+mo: abum- } \\
\text { dart base-netal } \\
\text { sulfides }\end{array}$ & Greisen & $\begin{array}{l}\text { Late } \\
\text { Cretaceous }\end{array}$ & $\begin{array}{l}\text { minor } \\
(<3 \mathrm{~mole} \\
\left.\times \mathrm{CO}_{2}\right)\end{array}$ \\
\hline & Susan & $\begin{array}{l}\text { Granite }(83-94 \mathrm{Ma}) \\
\text { in limestones }\end{array}$ & $\begin{array}{l}\text { Ouartz veins with } \\
\text { motwf +sct; minor } \\
\text { sulfides }\end{array}$ & Greisen & 83 & $\begin{array}{l}\text { variable, } \\
(3-100 \text { mole } \\
\left.x \mathrm{CO}_{2}\right)\end{array}$ \\
\hline \multirow[t]{2}{*}{$\begin{array}{l}\text { Pusan- } \\
\text { Yangsan }\end{array}$} & Gyeongchang & $\begin{array}{l}\text { Granite }(83.7 \mathrm{Ma}) \text { in } \\
\text { volcanosedimentary } \\
\text { rocks }\end{array}$ & $\begin{array}{l}\text { Quartz veins with } \\
\text { motwf+schiabur- } \\
\text { dant gulfides, Ag- } \\
\mathrm{Pb}-\mathrm{Bi}-\mathrm{Sb} \text { sulfosalts }\end{array}$ & $\begin{array}{l}\text { Sericitic, } \\
\text { propylitic }\end{array}$ & $82.4 \pm 1.4$ & absent \\
\hline & Sannae & $\begin{array}{l}\text { Quartz wonzonite } \\
\text { (75.5 Ma) in } \\
\text { volcanic rocks }\end{array}$ & $\begin{array}{l}\text { Quartz veins with } \\
\text { motwf +schi minor } \\
\text { sulfides }\end{array}$ & $\begin{array}{l}\text { Potassic. } \\
\text { sericitic }\end{array}$ & $65 \pm 3$ & absent \\
\hline
\end{tabular}

\begin{tabular}{|c|c|c|c|c|c|c|}
\hline \multirow[b]{2}{*}{ Mine } & \multicolumn{2}{|c|}{ Pluid inclusions } & \multirow{2}{*}{$\begin{array}{l}\text { Estimated } \\
\text { pressure } \\
\text { (bars) }\end{array}$} & \multirow[b]{2}{*}{$\begin{array}{l}\text { Estinated } \\
\text { depths (m) }\end{array}$} & \multirow[b]{2}{*}{$\begin{array}{l}\text { Pluid } \\
\text { evolution }\end{array}$} & \multirow[b]{2}{*}{ Reference } \\
\hline & $\left.\operatorname{In}(\mathrm{C})^{3}\right)$ & $\begin{array}{c}\text { Salinity } \\
\text { (wt. } x \text { eq. NaCl) }\end{array}$ & & & & \\
\hline Cheongrang & $\begin{array}{c}150 \text { to } 400 \\
(>300)\end{array}$ & 0 to 6 & 100 to 260 & $* 1,000$ & $\begin{array}{l}\text { Boiling and later } \\
\text { meteoric water } \\
\text { mixing }\end{array}$ & This study \\
\hline Daehiwa & $\begin{array}{c}160 \text { to } 395 \\
(>250)\end{array}$ & 0 to 8 & 100 to 350 & 1,250 to 3,000 & $\begin{array}{l}\text { Meteoric water mixing } \\
\text { after fluid boiling } \\
\left(\mathrm{\infty}_{2} \text { effervescence) }\right.\end{array}$ & $\begin{array}{l}\text { So et al. (1983b) } \\
\text { Shelton et al. (1987) } \\
\text { Park and Choi (1974) } \\
\text { Kim (1985) }\end{array}$ \\
\hline Weolag & $\begin{array}{c}155 \text { to } 395 \\
(>250)\end{array}$ & 4 to 11 & $\approx 180$ & $\langle 1,000$ to 2,300 & $\begin{array}{l}\text { Heteoric water mixing } \\
\text { after fluid boiling } \\
\left(\mathrm{O}_{2} \text { effervescence ?) }\right.\end{array}$ & So et al. (1983a) \\
\hline Susan & $\begin{array}{c}105 \text { to } 385 \\
(22 \infty)\end{array}$ & 0 to 10 & $\approx 220$ & 800 to 2,500 & $\begin{array}{l}\mathrm{O}_{2} \text { effervescence } \\
\text { and later meteoric } \\
\text { water mixing }\end{array}$ & $\begin{array}{l}\text { So and Yun (in prep) } \\
\text { Park et al. (1981) }\end{array}$ \\
\hline Gyeongchang & $\begin{array}{l}190 \text { to } 550 \\
(>300)\end{array}$ & 1 to 33 & 300 to 500 & 1,200 to 2,000 & $\begin{array}{l}\text { Meteoric water wixing } \\
\text { after liquid } \\
\text { condensation from } \\
\text { magsuatic vapor }\end{array}$ & So et al. (1991) \\
\hline Sannae & $\begin{array}{c}180 \text { to } 555 \\
(>300)\end{array}$ & 5 to 25 & 100 to 300 & $* 1,250$ & $\begin{array}{l}\text { Meteoric water mixing } \\
\text { after fluid boiling }\end{array}$ & Shelton et al. (1986) \\
\hline
\end{tabular}

1) $\$$ to minerals (wo = molybdenite, $s c h=$ scheelite, $w f=$ wolframite) are arranged in orders of decreasing abuniance

2) Data in parentheses are estimated $\mathrm{W}_{2}$ contents of liquid $\mathrm{CO}_{2}$-bearing inclusions

3) Data in parentheses are estimated temperatures of $\mathrm{WHo}$ deposition

South Korea occur in three major mining dis. tricts: Hwanggangri, Pusan-Yangsan, and Cheongyang. Table 3 summarizes some features of Korean vein-type W-Mo deposits, including the results of fluid inclusion studies.
These deposits display similarities in geologic setting, mineralogy and paragenesis, alteration assemblages and mineralization age.

All of the vein-type $\mathrm{W}$-Mo mineralization in Korea are of late Cretaceous age (65-88 Ma), 


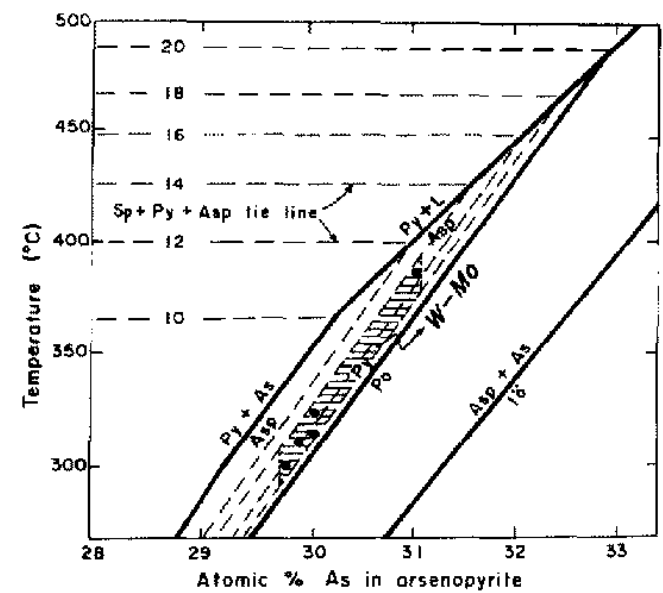

Fig. 8. Temperature versus atomic $\%$ As (in arsenopyrite) diagram, showing temperature conditions (hatched area) pertinent to pyrite-sphalerite-arsenopyrite assemblages (black dots) in early W-Mo mineralization of the Cheongyang $\mathrm{W}-\mathrm{Mo}$ mine (after Hutchison and Scott, 1981 ; Scott, 1983). Numbered dashes indicate compositional isopleths of sphalerite (mole \% FeS) in equilibrium with pyrite.

Abbreviations: As, arsenic ; Asp, arsenopyrite; L, arsenic-sulfur liquid; lö, löellingite; $\mathrm{Po}$, pyrrhotite; $\mathrm{Py}$, pyrite.

and are associated intimately with Cretaceous Bulgugsa granites, not with Jurassic Daebo granites. Cretaceous granites in Korea were solidified at shallower portions $(<2-3 \mathrm{~km})$ than Jurassic granites ( $>5 \mathrm{~km}$, Tsusue et al., 1981 ; Watanabe, 1981). Therefore, it is likely that the deposition of tungsten and molybdenum occurred as a result of lower pressures and depths of hydrothermal systems associated with shallow Cretaceous granitic activity (Ishihara et al, 1981). However, fluid inclusion data from these Korean W-Mo vein deposits are variable, as follows.

W-Mo vein deposits in the Hwanggangri mine district (e.g., Daehwa, Weolag, Susan) are characterized by the common occurrence of liquid $\mathrm{CO}_{2}$-bearing fluid inclusions (Table 3). The peculiar occurrence of $\mathrm{CO}_{2}$-bearing inclusions seems not to have been tied genetically to

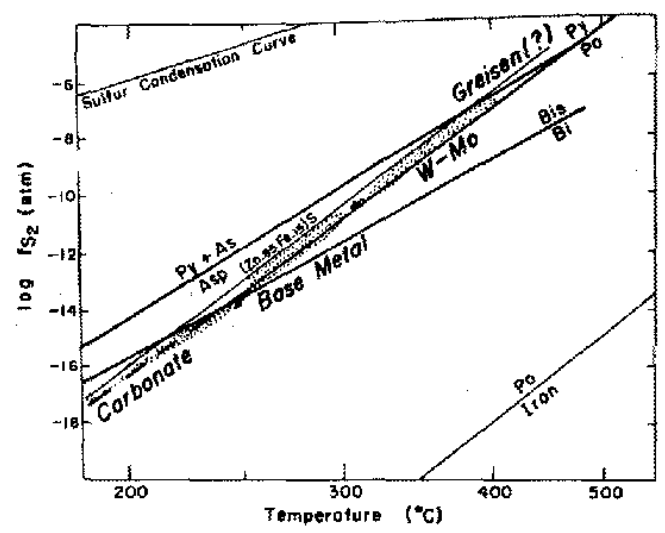

Fig. 9. $\log a \mathrm{~S}_{2}$ versus temperature diagram showing depositional conditions for W-Mo mineralization of the Cheongyang W-Mo mine (dotted area) (after Kretshmar and Scott, 1976). Numbered lines indicate compositional isopleths of arsenopyrite (atom. \% As).

Abbreviations: As, arsenic ; Asp, arsenopyrite ; $L$, liquid; Io, löellingite ; $\mathrm{Po}$, pyrrhotite; Py, pyrite.

specific host rock petrology (namely, the association of carbonate-rich wall rocks) because carbonate-rich rocks are absent in the Daehwa mine area. If depth (pressure) were one of the controlling factors for the occurrence of $\mathrm{CO}_{2}$ bearing inclusions, then mineralization depths for the $\mathrm{W}-\mathrm{Mo}$ vein deposits in the Hwanggangri district might have been deeper than those for the deposits in the Cheongyang and PusanYangsan mine district. Estimated depths of $\mathrm{W}$-Mo mineralization at the Hwanggangri district range from 800 to $3,000 \mathrm{~m}$. Previous fluid inclusion studies also suggest that W-Mo depo. sition in the Hwanggangri district was likely a combined result of fluid boiling (and $\mathrm{CO}_{3}$ effervescence) and later meteoric water mixing.

W-Mo vein deposits in the Pusan-Yangsan mine district (e.g., Gyeongchang, Sannae) are characterized by higher temperatures (up to $550^{\circ} \mathrm{C}$, which is close to the solvus temperature of granitic melts) and salinities (up to 25-33 wt. $\%$ eq. $\mathrm{NaCl}$ ) of ore-forming fluids (Table 3 ). Liquid $\mathrm{CO}_{2}$-bearing fluid inclusions are absent. 


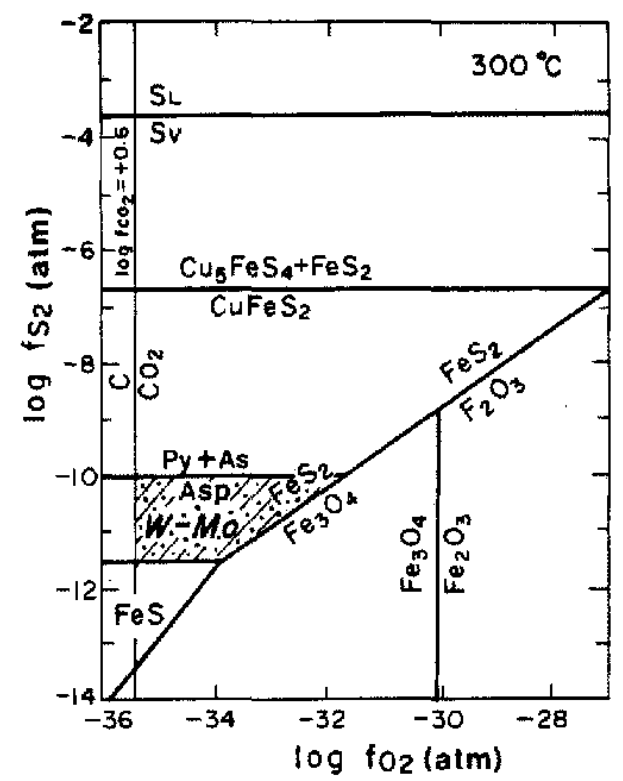

Fig. 10. Log $\mathrm{fs}_{2}$ versus $\log \mathrm{fo}_{2}$ diagram at $300^{\circ} \mathrm{C}$ showing stability fields of pyritepyrrhotite assemblages in W-Mo mineralization (dotted area) of the Cheongyang $\mathrm{W}$-Mo mine. Stability of graphite is based on a $\log \mathrm{f}_{\mathrm{CO}_{\mathrm{z}}}=0.6 \mathrm{~atm}$.

$\mathrm{Cu}-\mathrm{W}$-bearing hydrothermal breccia pipe deposits of the Ilkwang mine (mineralization age, $69 \pm 3 \mathrm{Ma}$; host rock, quart $z$ monzonite) in the Pusan-Yangsan district also formed from high" temperature $\left(305^{\circ}-458^{\circ} \mathrm{C}\right)$, high - salinity $\left(5^{\text {* }}\right.$ 23 wt. \% eq. $\mathrm{NaCl}$ ) fluids (So and Shelton, 1982). According to So et al. (1991), the high-temperature, high-salinity fluids for W-Mo deposition at Gyeongchang formed by liquid condensation during isothermal or adiabatic decompression of a magmatic, intermediate-salinity vapor phase. The decompression of magmatic vapor was likely the result of rapid rise of a magmatic plume without significant heat loss (Henley and McNabb, 1978; So et al., 1991). Granitoids in the Pusan-Yangsan district, especially the socalled "Masanite" (the Masan granites) which is the youngest members of the late CretaceousTertiary granites in Korea, are considered to be evolved Bulgugsa magmas and much shallower depth $(<2 \mathrm{~km})$ intrusions (Jin et al., 1981;

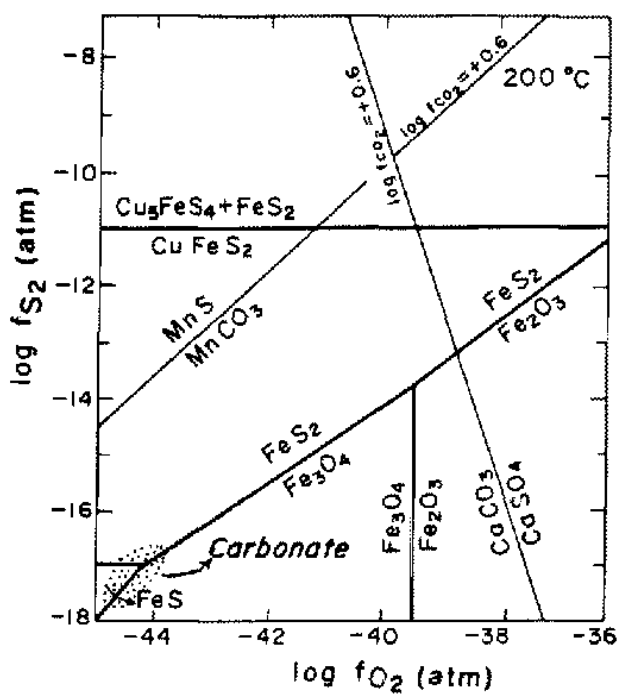

Fig. 11. Log $\mathrm{fs}_{2}$ versus $\log \mathrm{fo}_{2}$ diagram at $200^{\circ} \mathrm{C}$ showing stability fields of pyrite-magnetite-sphalerite-rhodochrosite-calcite assemblages in vug-stage (carbonate) mineralization (dotted area) of the Cheongyang W-Mo mine. Stabilities of rhodochrosite and calcite are based on a $\log \mathrm{f}_{\mathrm{CO}_{2}}=0.6 \mathrm{~atm}$.

Tsusue et al., 1981). Therefore, we suggest that rapidly rising magmatic fluids evolved from shallow-depth granitic intrusions at the Pusan-Yangsan district could result in formation of high-temperature and high-salinity, WMo-bearing hydrothermal fluids and further result in transport and deposition of W-Mo minerals at higher levels in the hydrothermal system. From the Gyeongchang mine, the occurence of $\mathrm{Pb}-\mathrm{Ag}-\mathrm{Bi}$-bearing sulfosalts and the previous production of gold from upper vein portions may further indicate that early WMo-deposited fluids cooled greatly at shallow depths.

Our fluid inclusion data from the Cheongyang mine are quite similar to those from the Hwanggangri mine district, except that liquid $\mathrm{CO}_{2}$-bearing inclusions are rare at Cheongyang (Table 3). This rarity of $\mathrm{CO}_{2}$-bearing fluid inclusions at Cheongyang is probably related 
Table 4. Surfur isotope data of sulfide minerals from the Cheongyang W-Mo mine

\begin{tabular}{|c|c|c|c|c|c|c|c|}
\hline Vein & $\begin{array}{l}\text { Level- } \\
\text { stage }\end{array}$ & $\begin{array}{c}\text { Mineralization } \\
\text { phase }\end{array}$ & $\begin{array}{c}\text { Sample } \\
\text { no. }\end{array}$ & Minerel & $8^{34} S(\%)$ & $\left.T(C)^{1}\right)$ & $\left.\delta^{34} \mathrm{SHzS}_{\mathrm{H}}\left(\%_{0}\right)^{2}\right)$ \\
\hline \multirow[t]{3}{*}{ East No, 2} & +2-greisen & greisen & $2 \mathrm{~B}-\mathrm{SI}$ & molybdenite & 4.7 & 370 & 3.6 \\
\hline & & greisen & $2 \mathrm{R}-\mathrm{S2}$ & pyrite & 4.3 & 370 & 3.3 \\
\hline & +2 -vein & base-gletal sulfides & $2 \mathrm{E}-\mathrm{S3}$ & pyrite & 4.9 & 300 & 3.7 \\
\hline \multirow[t]{4}{*}{ Central } & -3 -greisen & greisen & $3 C-51$ & pyrite & 4.9 & 380 & 4.0 \\
\hline & -3-vein & $H-M o$ & $3 \mathrm{C}-\mathrm{S} 2$ & pyrate & 4.6 & 330 & 3.5 \\
\hline & & W-Mo & $3 C-53$ & pyrite & 4.5 & 350 & 3.5 \\
\hline & & base-metal sulfides & $3 \mathrm{C}-\mathrm{S4}$ & pyrite & 5.0 & 300 & 3.8 \\
\hline \multirow[t]{11}{*}{ Main } & -1-vein & base-netal sulfides & $1 M-S 1$ & pyrite & 4.5 & 280 & 3.2 \\
\hline & & base-metal sulfides & 1M S2 & chalcopyrite & 4.2 & 280 & 4.4 \\
\hline & $-1-v u g$ & vug(carbanate) & $1 M-S 3$ & pyrite & 4.8 & 250 & 3.3 \\
\hline & -2-greisen & greisen & $2 \mathrm{M}-\mathrm{S} 1$ & pyrite & 5.0 & 380 & 4.1 \\
\hline & -2-vein & W-Mo & $2 M-S 2$ & molybdenite & 4.4 & 350 & 3.2 \\
\hline & -3 vein & base-metal sulfides & $3 \mathrm{M}-\mathrm{S1}$ & pyrite & 5.1 & 280 & 3.8 \\
\hline & & base-metal sulfides & $3 M-S 2$ & chalcopyrite & 4.5 & 280 & 4.7 \\
\hline & $-3-v u g$ & vug(carbonate) & $3 M-53$ & pyrite & 4.9 & 250 & 3.4 \\
\hline & -4-greisen & greisen & $4 M-51$ & pyrite & 4.7 & 370 & 3.7 \\
\hline & $-4-v e i n$ & W-Mo & $4 M-52$ & molybdenite & 4.5 & 350 & 3.3 \\
\hline & & base-metal sulfides & $4 M-53$ & pyrite & 5.9 & 270 & 4.5 \\
\hline
\end{tabular}

1) Based on fluid inclusion temperatures and paragenetic constraints

2) Calculated using the sulfur isotope fractionation equations in Ohmoto and Rye (1979)

with more extensive $\mathrm{CO}_{2}$ loss from hydrothermal fluids due to fluid boiling at shallower depths. More complexity of vein mineralogy, including the occurrence of $\mathrm{Pb}-\mathrm{Bi}$ sulfosalts, may also reflect shallower depths of W-Mo mineralization at Cheongyang compared to deposits in the Hwanggangri district. Therefore, fluid inclusion characteristics of Korean hydrothermal W-Mo vein deposits may be a useful guide to the influence of depth of emplacement on postmagmatic evolution of granite-related W-Mo systems and may help to delineate metallogenic provinces of $\mathrm{W}$ and $\mathrm{Mo}$ in Korea.

\section{Redox and sulfur chemistry of miner- alization}

The physicochemical constraints of mineral deposition at Cheongyang can be estimated by ore and gangue mineral assemblages in relation to time and space, combined with chemical compositions of ore minerals and fluid inclusion data.

\section{Vein-Stage Mineralization}

(7) Early $W$-Mo Mineralization: Wol. framite and molybdenite in early vein mineral. ization are associated with minor amounts of pyrite, arsenopyrite (29.7-31.0 atom. \% As), and sphalerite (15.3-19.2 mole \% FeS). Formation temperatures for the W-Mo mineralization can be estimated using the compositions of coexisting sphalerite and arsenopyrite (black dots in Fig. 8). Estimated temperatures for W-Mo mineralization range from $\approx 300^{\circ}$ to $380^{\circ} \mathrm{C}$ (hatched area in Fig. 8), which are in good agreement with W-Mo deposition temperatures $\left(300^{\circ}-400^{\circ} \mathrm{C}\right)$ estimated from fluid inclusion homogenization temperatures. Based on these temperatures, the sulfidation state for $\mathrm{W}-\mathrm{M}_{0}$ mineralizing fluids can be constrained by mineral stability in the system $\mathrm{Fe}-\mathrm{As}-\mathrm{S}$ (Kretschmar and Scott, 1976). The stability of pyriteit 
Table 5. Carbon, oxygen, and hydrogen isotope data for various minerals and inclusion fluids, Cheongyang $\mathrm{W}$-Mo mine

\begin{tabular}{|c|c|c|c|c|c|c|c|c|c|c|}
\hline Vein & $\begin{array}{l}\text { Level- } \\
\text { stage }\end{array}$ & $\begin{array}{c}\text { Sample } \\
\text { no. }\end{array}$ & Mineral & $\begin{array}{c}\text { Mineralization } \\
\text { phase }\end{array}$ & ${ }^{8}{ }^{3} \mathrm{C}(\%)$ & $5^{18} 8\left(\Psi_{00}\right)$ & $\delta \mathrm{D}\left(\%_{a s}\right)$ & $T(\mathrm{C})$ & sloownter $\left.\left(\xi_{\text {wod }}\right) 2\right)$ & SDwater $\left(\eta_{s t}\right)$ \\
\hline \multirow[t]{3}{*}{ Esst. No. 2} & +2 -greisen & $2 E-1$ & mus & greigen & & 8.7 & -96 & 370 & 6.8 & $-64^{31}$ \\
\hline & +2 -vein & $2 B-2$ & $q t z$ & W-Ho & & 12.9 & - & 350 & 7.6 & -69 \\
\hline & +2 -yein & $2 \mathrm{~B}-3$ & qtz & base-metal sulfides & & 10.6 & - & 300 & 3,7 & -67 \\
\hline \multirow[t]{3}{*}{ Central } & -3 -vein & $3 c-1$ & $w f$ & W-Mo & & 5.6 & - & 320 & 7.0 & - \\
\hline & & $3 \mathrm{C}-2$ & gtz & $k \rightarrow k 0$ & & 13.6 & - & 330 & 7.8 & -69 \\
\hline & -3 -vug & $3 c-3$ & gtz & vug(carbonate) & & 7.5 & - & 250 & -1.4 & -67 \\
\hline \multirow[t]{10}{*}{ Main } & $-1-\operatorname{vug}$ & $1 M-1$ & rd & vug(carbonate) & & 7.2 & - & 260 & 0.3 & - \\
\hline & -2-greisea & $2 \mathrm{~N}-1$ & $q t z$ & greisen & & 11.1 & - & 380 & 6.6 & -71 \\
\hline & -2 -vein & $2 M-2$ & qez & $n-16$ & & 13.1 & - & 350 & 7.8 & - \\
\hline & & $2 x-3$ & nus & $W_{10}$ & & 9.9 & -108 & 340 & 7.5 & $-6 \mathrm{~B}^{33}$ \\
\hline & -z-yein & $24-4$ & $q \in 2$ & babe-netal oulfideg & & 10.3 & - & 280 & 2.7 & -64 \\
\hline & $-2-v x g$ & $2 M-5$ & qtz & vag (carbonate) & & 8.9 & - & 260 & 0.5 & -69 \\
\hline & & $24-6$ & rd & viggicarbonate) & -7.0 & 8.2 & - & 265 & 1.5 & - \\
\hline & $-3-q x e z ̇ в$ & $3 M-1$ & qtz & greisen & & 10.6 & - & 390 & 6.3 & -70 \\
\hline & -3 -vein & $3 \mathrm{H}-2$ & wI & h้-80 & & 5.5 & 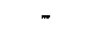 & 330 & 7.2 & - \\
\hline & $-3-$ yug & $3 \mathrm{M}-3$ & $\mathrm{cc}$ & vug(carbonate) & -5.5 & 10.8 & - & 220 & 2.3 & - \\
\hline
\end{tabular}

1) Besed on fluid inclusion tenperatures and paragenetic constraints

2) Calculated using the following oxygen isotope fractionation equations: quartz-water, Matsuhisa et al. (1979);

calcite(and rhodochrosite)-water, 0 Neil et al. (1969); muscovitewater, Friedman and 0 Neil (1977); and wolframite-water, Landis and Rye (1974).

3) Calculated using the hydrogen isotope fractionation equation of Suzuoki and Epatein (1976).

Abbreviations: GC = calcite, mus = Euscovite, qtz a quartz, rd = rhodochrosite, wf = wolframite

arsenopyrite + sphalerite assemblage in the $\mathrm{W}$ Mo stage indicates the $\log \mathrm{fs}_{\mathrm{z}}$ (atm) values of $\approx-10.3$ to -7.0 , as shown in Figure 9 .

The probable $\mathrm{fo}_{2}$ conditions for the $\mathrm{W}-\mathrm{Mo}$ mineralization can be drawn on the $\log \mathrm{fs}_{2}$ versus log $\mathrm{fo}_{2}$ diagram (Fig. 10). The diagram has been constructed for $300^{\circ} \mathrm{C}$ (the lower end of estimated temperatures for W-Mo mineralization) where pyrrhotite is stable along with pyrite and wolframite. Assuming a $\log \mathrm{fcO}_{2}$ value of $0.6 \mathrm{~atm}$ (based on the general absence of liquid $\mathrm{CO}_{2}$-bearing inclusions), the minimum $\log \mathrm{fo}_{2}$ value for W-Mo mineralization is defined by the $\mathrm{C}-\mathrm{CO}_{2}$ curve because graphite is absent. The estimated $\log \mathrm{fo}_{2}$ (atm) values range from $\approx-35.5$ to -32.0 (Fig. 10 ).

(2) Late Base-Metal Sulfide Mineralization: During periods of base-metal sulfide mineralization, pyrrhotite was precipitated as an important $\mathrm{Fe}-\mathrm{S}$ mineral. Fluid inclusion data indicate that deposition of base-metal sulfides occurred at temperatures below $300^{\circ} \mathrm{C}$. The probable range of $\log \mathrm{fs}_{2}$ (atm) values for the base-metal sulfide mineralization can be estimated to be $\approx-11.0$ to -13.5 by the pyritepyrrhotite reaction curve (Fig. 9).

\section{Vug-Stage Mineralization}

Pyrite, pyrrhotite, magnetite and sphalerite (18.3-23.4 mole \% FeS) were deposited in vugs, together with native bismuth, carbonates and fluorite. Pyrrhotite and sphalerite were deposited only during early periods of vug-stage mineralization. The early assemblage pyrrhotite-sphalerite-magnetite-bismuth can be used to estimate fugacities of sulfur and oxygen during vug-stage mineralization. Estimated temperature and fugacity of sulfur ( $\log$ $\mathrm{fs}_{2}$ ) for vug-stage (carbonate) mineralization are about $\angle 250^{\circ} \mathrm{C}$ and $<-14$ atm, respectively (Fig. 9). Figure 9 also shows a general decrease in $\log \mathrm{fs}_{2}$ (atm) values with increasing paragenetic time from $\approx-7$ (for $\mathrm{W}$-Mo mineralization) to $<-16$ (for carbonate mineralization). Assuming a temperature of $200^{\circ} \mathrm{C}$ for carbonate mineralization in vugs, a $\log \mathrm{fs}_{2}$ versus $\log \mathrm{fo}_{2}$ diagram was constructed (Fig, 11). The assem. 


\section{G GREISEN STAGE}
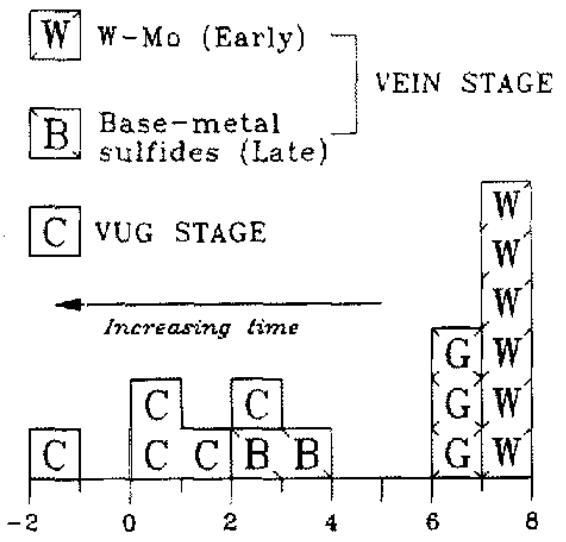

Calcualted $\delta^{18} \mathrm{O}_{\text {water }}(\%)$

Fig. 12. Variation of calculated oxygen isotope composition of waters in equilibrium with various minerals from the Cheongyang W-Mo mine.

blage pyrite (-pyrrhotite)-magnetite indicates $\log \mathrm{fo}_{2}$ values near -44 atm (Fig. 11).

\section{Stable isotope studies}

In order to elucidate the origin and evolution of hydrothermal fluids and their constituents in the Cheongyang W-Mo deposits, we measured sulfur isotope compositions of 18 sulfides, carbon isotope compositions of 3 carbonates (calcite, rhodochrosite), oxygen isotope compositions of 9 quart $z, 3$ carbonates, 2 muscovites and 2 wolframites, and hydrogen isotope compositions of 2 muscovites and 8 fluid inclusion waters extracted from quartz. Gas extraction techniques for the mass spectrometer analysis were taken from McCrea (1950) for carbonates, Grinenko (1962) for sulfides, Hall and Friedman (1963) and Roedder et al. (1963) for fluid inclusions, and Rye and Sawkins (1974) for silicates, respectively. Isotopic data are reported in standard $\delta$ notation relative to the CDT standard for sulfur, the PDB standard for carbon, and the Vienna
SMOW standard for oxygen and hydrogen. The standard errors of each analysis are about \pm 0.1 per mil for sulfur, carbon, and oxygen, and \pm 2 per mil for hydrogen (Tables 4 and 5).

\section{Sulfur Isotope Study}

Sulfur isotope compositions of handpicked sulfide minerals (13 pyrites, 3 molybdenites, 2 chalcopyrites) are shown in Table 4. The sulfides have nearly uniform $\delta^{34} \mathrm{~S}$ values ranging from 4.2 to 5.9 per mil. There is no spatial variation in the $\delta^{34} \mathrm{~S}$ values of sulfide minerals from the ore veins within the deposits.

Assuming depositional temperatures of $350^{\circ}$ to $400^{\circ} \mathrm{C}$ for sulfides from greisen stage, $300^{\circ}$ to $350^{\circ} \mathrm{C}$ for sulfides from early W-Mo mineralization in veins, $270^{\circ}$ to $300^{\circ} \mathrm{C}$ for sulfides from late base-metal sulfide mineralization in veins, and $220^{\circ}$ to $270^{\circ} \mathrm{C}$ for sulfides from vug (carbonate) stage, based on paragenetically constrained temperature estimates (using fluid inclusion homogenization temperatures), the ranges of possible $\delta^{34} \mathrm{~S}_{\mathrm{H}_{2} \mathrm{~S}}$ values of the hydrothermal fluid were calculated (using the compiled data of Ohmoto and Rye, 1979) (Table 4): greisen-stage sulfides, 3.3 to 4.1 per mil ; early W-Mo-stage sulfides, 3.2 to 3.5 per mil ; late base-metal-stage sulfides, 3.2 to 4.7 per mil; and vug-stage sulfides, 3.3 to 3.4 per mil. There is no recognizable temporal variations of the calculated $\delta^{34} \mathrm{~S}_{\mathrm{H}_{2} \mathrm{~S}}$ values of hydrothermal fluids.

Overlap of the ranges of calculated $\delta^{34} \mathrm{~S}_{\mathrm{H}} \mathrm{s}$ values suggests that a fluid with a $\delta^{34} \mathrm{~S}_{\mathrm{H}_{2} \mathrm{~s}}$ value near 4 per mil was responsible for mineraliza tion at Cheongyang. The small variation of $\delta^{34} \mathrm{~S}_{\mathrm{H}_{2} \mathrm{~S}}$ values over a temperature range of $400^{\circ}$ to $220^{\circ} \mathrm{C}$, and the assemblages of pyrite ( pyrrhotite)-magnetite in veins and of muscovite (-K-feldspar)-quartz in alteration zones indicate that sulfur in the fluid was dominantly $\mathrm{H}_{2}$ $\mathrm{S}$ (Ohmoto, 1972). Therefore, the $\delta^{34} \mathrm{~S}_{\mathrm{H}_{2} \mathrm{~S}}$ value near 4 per mil may be taken as an approxima- 


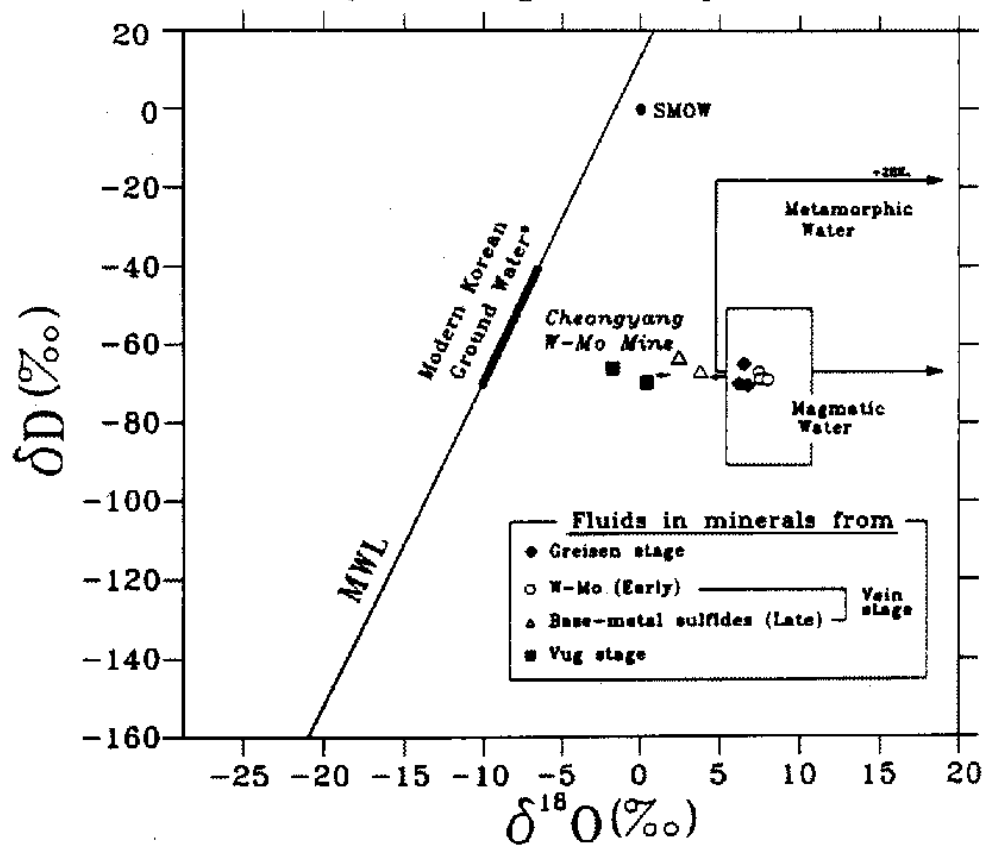

Fig. 13. Hydrogen versus oxygen isotope diagram showing temporal variation of stable isotope compositions of the Cheongyang hydrothermal fluids. Meteoric water line is from Craig (1961); magmatic and metamorphic water boxes are from Taylor (1974). Range of isotopic compositions of modern Korean groundwaters $\left({ }^{*}\right)$ is from Kim and Nakai (1988).

tion of the sulfur isotope composition of the entire hydrothermal fluids. This $\delta^{34} \mathrm{~S}_{\Sigma s}$ value near 4 per mil indicates that the primary source of sulfur in the Cheongyang hydrothermal fluids was an igneous source (Ohmoto and Rye, 1979), likely the host granite porphyry.

\section{Carbon, Oxygen, and Hydrogen Isotope Study}

The $\delta^{13} \mathrm{C}, \delta^{18} \mathrm{O}$ and $\delta \mathrm{D}$ values for various minerals and inclusion fluids are summarized in Table 5.

Carbonate minerals ( 2 rhodochrosites and 1 calcite) for the vug(carbonate)-stage have $\delta^{13} \mathrm{C}$ values of -7.0 to -5.5 per mil. The $\delta^{18} \mathrm{O}$ values of the carbonate minerals are 7.2 to 10.8 per mil. Using the calcite-water oxygen isotope fractionation equation of O'Neil et al. (1969), coupled with temperature estimates based on fluid inclusion and paragenetic constraints, the range of $\delta^{18} \mathrm{O}$ values of waters in equilibrium with the carbonates is 0.3 to 2.3 per mil (for this calculation, the oxygen isotope fractionation between rhodochrosite and water was assumed to be approximate that between calcite and water) (Table 5).

The $\delta^{38} \mathrm{O}$ values of quartz, muscovite and wolframite are (Table 5) : quartz, 7.5 to 13.6 per mil [greisen-stage quartz, 10.6-11.1 per mil; W-Mo-stage quartz, 12.9-13.6 per mil ; basemetal-stage quartz, 10.3-10.6 per mil ; vug(carbonate)-stage quartz, 7.5-8.9 per mil]; muscovite, 8.7 to 9.9 per mil ; and wolframite, 5.5 to 5.6 per mil. Using the appropriate oxygen isotope fractionation equations, coupled with the estimated temperatures based on paragenetic constraints and fluid inclusion data, the oxygen isotope compositions of waters in the hydrothermal fluids are calculated as follows (Table 5) : greisen stage, 6.3 to 6.8 per mil ; early $\mathrm{W}-\mathrm{Mo}$ mineralization in the vein stage, 7.0 to 7.8 per mil; late base-metal sulfide mineralization in the vein stage, 2.7 to 3.7 per mil ; quartz deposition in the vug stage, -1.4 to 0.5 per mil. 
The $\delta \mathrm{D}$ values of 2 muscovites are -98 and -108 per mil (Table 5). Assuming depositional temperatures based on fluid inclu. sions in associated quart $z$, the calculated $\delta \mathrm{D}$ values of waters in equilibrium with muscovite are -64 and -68 per mil (using the hydrogen isotope fractionation equation of Suzuoki and Epstein, 1976)

Inclusion waters extracted from 8 quart $z$ samples were analyzed for hydrogen isotope compositions (Table 5). The $\delta \mathrm{D}$ values of inclusion waters from quartz have a narrow range from -71 to -64 per mil.

\section{Interpretation of Oxygen and Hydrogen Isotope Results}

The $\delta^{18} \mathrm{O}_{\text {water }}$ values of hydrothermal fluids decrease systematically with increasing paragenetic time, from $\approx 8$ per $\mathrm{mil}$ for greisen stage and $\mathrm{W}-\mathrm{M}_{0}$ mineralization, to $\approx 3$ per mil for base-metal sulfides mineralization, to $\approx-2$ per mil for vug(carbonate)-stage deposition (Fig. 12). This decrease of $\delta^{15} \mathrm{O}_{\text {water }}$ values with time indicates a progressive increase of meteoric water interaction in the Cheongyang hydrothermal system.

There is a slight increase of $\delta^{18} \mathrm{O}_{\text {water }}$ values from the greisen stage $\left(\delta^{18} \mathrm{O}_{\text {water }}=6.3\right.$ to 6.8 per mil) to the early W-Mo mineralization in vein stage $\left(\delta^{18} \mathrm{O}_{\text {water }}=7.0\right.$ to 7.8 per mil) (Table 5, Fig. 12). This small positive change in $\delta^{18} \mathrm{O}_{\text {water }}$ values may coincide with fluid boiling documented in fluid inclusion studies [vaporrich type $\mathrm{II}$ inclusions $\left(\mathrm{Th}{ }^{\circ} \mathrm{C}=310^{\circ}-390^{\circ} \mathrm{C}\right.$ ) were observed exclusively in white quartz and beryl from vein stage]. Boiling of ore fluids during W-Mo mineralization could result in preferential loss of ${ }^{16} \mathrm{O}$-enriched vapor, resulting in higher $\delta^{18} \mathrm{O}_{\text {water }}$ values for the residual mineralizing fluid (Friedman and O'Neil, 1977).

Figure 13 shows the distribution of measured and calculated hydrothermal water compositions from the Cheongyang mine on a $\delta \mathrm{D}$ vs. $\delta^{18} \mathrm{O}$ diagram. The data from the greisen to W-Mo mineralization stages fall within the calculated range of primary magmatic waters in equilibrium with normal igneous rocks (Taylor, 1974) and may therefore represent magmatic water or water from any source whose isotopic composition was controlled by isotopic exchange with a large volume of granitoids at near magmatic temperatures.

Quartz from the base-metal sulfide stage yielded isotopic values for fluids which fall significantly outside the range of magmatic waters toward more negative $\delta^{18} \mathrm{O}$ values (Fig. 13). This could represent mixing of magmatic or highly exchanged meteoric water with less exchanged meteoric water, or exchange of meteoric water with granitic rocks at elevated temperatures and low water/rock ratios. Data from the vug (carbonate) stage (Fig. 13) are consistent with mixing of highly exchanged meteoric water with unexchanged meteoric water or exchange of meteoric water with granitic rocks at elevated temperatures and high water/rock ratios. Using either a mixing or exchange model, the isotopic compositions of fluids in the Cheongyang hydrothermal system show a progressive shift from magmatic hydrothermal dominance in the W-Mo stage toward meteoric hydrothermal dominance in the base-metal sulfide and vug (carbonate) stages.

Acknowledgements: This research was supported by a grant from the Korea Science and Engineering Foundation. Isotopic analyses and sample preparation was partially aided by the Center for Mineral Resources Research. The authors thank Dr. K.L. Shelton of the University of Missouri-Columbia for his helpful comments on the manuscript. This paper was improved by helpful comments from two anonymous reviewers. 


\section{References}

Bozzo, A.T., Chen, H.S., Kaas, J.R. and Barduhn, A.J. (1975), The properties of hydrates of chlorine and carbon dioxide. Desalination, 16, $303-320$.

Campbell, A.R. (1983), Genesis of the tungstenbase-metal ores at San Cristobal, Peru. Ph.D. thesis. pp. 176, Harvard Univ.

Collins, P.L.F. (1979), Gas hydrates in $\mathrm{CO}_{2}$-bearing fluid inclusions and the use of freezing data for estimation of salinity. Econ. Geol., 74, $1435-1444$.

Craig, H. (1961), Isotopic variations in meteoric waters. Science, 133, 1702-1703.

Drummond, S.E. and Ohmoto, H. (1985), Chemical evolution and mineral deposition in boiling hydrothermal systems. Econ. Geol., 80, 126147.

Friedman, I. and O'Neil, J.R. (1977), Compilation of stable isotope fractionation factors of geochemical interest. In Data of Geochemistry (Fleischer, M. Ed.). U. S. Geol. Survey Prof. Paper $440-\mathrm{KK}$, KK1-KKl2.

Grinenko, V.A. (1962), Preparation of sulfur dioxide for isotopic analysis. Zeitschr. Neorganisch Khimii., 7, 2478-2483.

Haas, J.L., Jr. (1971), The effect of salinity on the maximum thermal gradient of a hydrothermal system at hydrostatic pressures. Econ. Geol., 66, 940-946.

Hall, W.E. and Friedman, I. (1963), Compositions of fluid inclusions, Cave-in-Rock fuorite district, Illinois, and Upper Mississippi Valley lead-zinc district. Econ. Geol, 58, 886-911.

Hedenquist, J.W. and Henley, R.W. (1985), The importance of $\mathrm{CO}_{2}$ on freezing point measurements of fluid inclusions: evidence from active geothermal systems and implications for epithermal ore deposition. Econ. Geol, 80, 1379-1406.

Henley, R.W. and McNabb, A. (1978), Magmatic vapor plumes and ground-water interaction in porphyry copper emplacement. Econ. Geol., 73, 1-20.

Hollister, L.S, and Burruss, R.C. (1976), Phase equilibria in fluid inclusions from the Khtada Lake metamorphic complex. Geochim. Cosmochim. Acta, 40, 163-175.

Hutchison, M.N. and Scott, S.D. (1981), Sphalerite geobarometry in the $\mathrm{Cu}-\mathrm{Fe}-\mathrm{Zn}-\mathrm{S}$ system. Econ. Geol., 76, 143-153.

Ishihara, S., Lee, D.S. and Kim, S.Y. (1981), Com- parative study of Mesozoic granitoids and related W-Mo mineralization in Southern Korea and Southwestern Japan. Mining Geol, 31, 311-320.

Jin, M.S., Kim, S.Y. and Lee, J.S. (1981), Granitic magmatism and associated mineralization in the Gyeongsang basin, Korea. Mining Geol, $31,245-259$.

Kelly, W.C. and Rye, R.O. (1979), Geologic, fluid inclusion, and stable isotope studies of the tintungsten deposits of Panasqueira, Portugal. Econ. Geol., 74, 1721-1822.

Kim, D.R. (1985), A study on genesis of the Daehwa tungsten-molybdenum deposits. Unpub. Ms. thesis. pp. 81, Seoul Nat'l Univ. (in Kor. ean).

Kim, K.H. (1977), Geologic and fluid inclusion studies of the Chongyang tungsten ore deposits, South Korea, Jour. Korea Inst. Mining Geol, 10, 1-18 (in Korean).

Kim, K.H. and Nakai, N. (1988), Isatopic compositions of precipitations and groundwaters in South Korea. Jour. Geol. Soc. Korea, 24, 37-46 (in Korean).

Kim, W.J. (1984), Tungsten and molybdenum ore deposits in South Korea. Geol. Soc. Japan Rept., no. 263, 253-268.

Kretschmar, U. and Scott, S.D. (1976), Phase relations involving arsenopyrite in the system $\mathrm{Fe}-$ As-S and their application. Can Mineral, 14, 364-386.

Landis, G.P. and Rye, R.O. (1974), Geologic, fluid inclusion, and stable isotope studies of the Pasto Bueno tungsten-base-metal ore deposit, Northern Peru. Econ. Geol., 69, 1025-1059.

Matsuhisa, Y., Goldsmith, R. and Clayton, R.N. (1979), Oxygen isotope fractionation in the system quartz-albite-anorthite-water. Geochim. Cosmochim. Acta, 43, 1131-1140.

McCrea, J.M. (1950), The isotopic chemistry of carbonates and a paleotemperature scale, $J$. Chem. Physics, 18, 849.

Ohmoto, H. (1972), Systematics of sulfur and carbon isotopes in hydrothermal ore deposits. Econ. Geol., 67, 551-578.

Ohmoto, H. and Rye, R.O. (1979), Isotopes of sulfur and carbon, In Geochemistry of hydrothermal ore deposits (Barnes, H.L. Ed.). New York, Wiley Intersci., 509-567.

O'Neil, J.R., Clayton, R.N. and Mayeda, T.K. (1969), Oxygen isotope fractionation in divalent metal carbonates. J. Chem. Physics, 51, 5547-5558.

Park, H.I. and Choi, S.W. (1974), A study on the 
fluid inclusions in the minerals from the Dae Hwa tungsten-molybdenum deposits. J. Korean Inst, Mining Geol., 7, 63-78 (in Korean).

Park, H.I. and Choi, S.W. (1981), Fluid inclusions from the Cheongyang tungsten deposits(abs.) : Geol. Soc. Korea Ann. Mtg., 1981(in Korean).

Park, H.I., Lee, S.M. and Kim, S.J. (1981), A study on the genesis of the metallic ore deposits in Hwanggangri region. I. Geol. Soc. Korea, 17, 201-222 (in Korean).

Polya, D.A. (1987), Chemical behaviour of tung. sten in hydrothermal fluids and genesis of the Panasqueira W-Cu-Sn deposit, Portugal. Unpub. Ph. D. thesis. pp. 334, Univ. Manches. ter.

Potter, R.W., III, Clynne, M.A. and Brown, D.I. (1978), Freezing point depression of aqueous sodium chloride solutions. Econ. Geol., 73, 284-285.

Roedder, E., Ingram, B. and Hall, W.E. (1963), Studies of fluid inclusions. III. Extraction and quantitative analysis of inclusions in the milligram range. Econ. Geol, 58, 353-374.

Rye, R.O. and Sawkins, F.J. (1974), Fluid inclusion and stable isotope studies on the Casapalca $\mathrm{Ag}-\mathrm{Pb}-\mathrm{Zn}-\mathrm{Cu}$ deposit, Central Andes, Peru. Econ. Geol., 69, 181-205.

Scott, S.D. (1983), Chemical behaviour of sphalerite and arsenopyrite in hydrothermal and metamorphic environments. Mineral. Mag, 47, 427-435.

Scott, S.D. and Barnes, H.L. (1971), Sphalerite geothermometry and geobarometry. Econ. Geol., 66, 653-669.

Shelton, K.L. (1983), Composition and origin of ore-forming fuids in a carbonate hosted porphyry copper and skam deposit. a fluid inclusion and stable isotopic study of Mines Gaspe Quebec. Econ. Geol., 78, 387-421.

Shelton, K.L. (1984), Interpretation of characteristic mineral parageneses in tungsten-molybdenum quartz vein-type deposits. Neues Jahrb. Mineralogie Monatsh., 1984, 455-460.

Sheiton, K.L.; Taylor, R.P. and So, C.S. (1987), Stable isotope studies of the Dae Hwa tungsten-molybdenum mine, Republic of Korea. evidence of progressive meteoric water interaction in a tungsten bearing hydrothermal system. Econ. Geol., 82, 471-481.
Shelton, K.L., So, C.S, Rye, D.M. and Park, M.E. (1986), Geologic, sulfur isotope, and fluid inclusion studies of the Sannae W-Mo mine, Repub. lic of Korea. comparison of sulfur isotope systematics in Korean W deposits. Econ. Geol., 81, 430-446.

So, C.S. and Shelton, K.L. (1982), A sulfur isotopic and fuid inclusion study of the $\mathrm{Cu}-\mathrm{W}$-bearing tourmaline breccia pipe, Ilkwang mine, Republic of Korea. Econ. Geol., 78, 326-332.

So, C.S., Rye, D.M. and Shelton, K.L. (1983a), Carbon, hydrogen, oxygen, and sulfur isotope and fluid inclusion study of the Weolag tungsten-molybdenum deposit, Republic of Korea. fluid histories of metamorphic and ore-forming events. Econ. Geol., 78, 1551-1573.

So, C.S., Shelton, K.L., Seidemann, D.E. and Skinner, B.J. (1983b), The Dae Hwa tungstenmolybdenum mine, Republic of Korea. a geochemical study. Econ. Geol., 78, 920-930.

So, C.S., Shelton, K.L., Chi, S.J. and Yun, S.T. (1991), Geochemical studies of the Gyeong. chang W-Mo mine, Republic of Korea. progressive meteoric water inundation of a mag. matic hydrothermal system. Econ. Geol., 86, 750-767.

Sourirajan, S. and Kennedy, G.C. (1962), The system $\mathrm{H}_{2} \mathrm{O}-\mathrm{NaCl}$ at elevated temperatures and pressures. Am. J. Sci., 260, 115-141.

Suzuoki, T. and Epstein, S. (1976), Hydrogen isotope fractionation between $\mathrm{OH}$-bearing minerals and waters. Geochim. Cosmochim. Acta, 40, $1229-1240$.

Taylor, H.P., Jr. (1974), The application of oxygen and hydrogen isotope studies to problems of hydrothermal alteration and ore deposition. Econ. Geol., 69, 843-883.

Tsusue, A., Mizuta, T., Watanabe, M. and Min, K. G. (1981), Jurassic and Cretaceous granitic rocks in South Korea. Mining Geol, 31, 260280.

Watanabe, M. (1981), Reconnaisance study on the fluid inclusions in some Jurassic and Cretaceous granitic rocks in the Republic of Korea. In Petrographic provinces of granitoids and associated metallic ore deposits in South Korean peninsula. ('Tsusue, A. Ed), Kumamoto, Japan, Kumamoto Univ., Over seas Field Research Rept., 109-124. 